\title{
Mesoscale slope current variability in the Gulf of Lions. Interpretation of in-situ measurements using a three-dimensional model
}

\author{
Gaël Andréa, ${ }^{*}$, Pierre Garreau ${ }^{a}$ and Philippe Fraunie ${ }^{b}$ \\ a IFREMER, DYNECO/PHYSED, BP 70, 29280 Plouzané, France \\ b Laboratoire de Sondages Electromagnétiques de l'Environnement Terrestre, Centre National de la Recherche \\ Scientifique UMR 6017, Université du Sud Toulon-Var, BP 20132, 83957 La Garde, France
}

*: Corresponding author : Gaël André, Tel.: 332982247 60; fax: 332982248 64, email address : Gael.Andre@ifremer.fr

\begin{abstract}
:
The ECOLOPHY experiments aimed at investigating physical exchanges between coastal and open sea. They were carried out in June and December 2005 over the shelf-break in the North-eastern part of the Gulf of Lions (Northwestern Mediterranean Sea). This area is considered to be the generation zone for the eddy and meandering structures of the Northern Current (NC). The objective of the present work is to examine mesoscale variability of this coastal slope current in the light of available data. Numerical modeling is used to support the field data analysis. ADCP current measurements over a one-year period show that mesoscale activity is maximal in late winter, correlating with the seasonal variability of the NC and, also, partly with local winds. Measured currents exhibit mesoscale fluctuations with periods ranging from 3 to 30 days, in agreement with previous analyses. Fluctuations of periods longer than 10 days are found to be mainly oriented in the direction of the mean current, whereas more frequently observed high frequency fluctuations tend to be oriented cross-slope, suggesting a relationship with the NC mesoscale meandering. Moreover, trajectories of surdrift buoys launched in the NC vein exhibit mesoscale phenomena, such as current meanders or eddies and onshelf intrusions. Numerical modeling provides a synoptic point of view and is used hereafter to support physical interpretation of punctual eulerian or lagrangian measurements. Therefore, modeled hydrodynamic fields are used to analyze surdrift buoy trajectories and computed vertically averaged current and Ertel potential vorticity provide a better understanding of these behaviors.
\end{abstract}

Keywords: Northwestern Mediterranean Sea; Gulf of Lions; Northern Current; Slope current; Mesoscale variability; Numerical modeling 


\section{Introduction}

\subsection{Background}

Coastal slope currents exhibit unstable behavior due to barotropic and baroclinic instabilities (Middleton and Cirano, 1999; Mysak et al., 1981), which generate mesoscale eddies and meanders resulting from number of interactions (wind forcing, tides, buoyancy, bathymetry ...). This kind of mechanisms can play a role on the current intrusions across the continental shelf and were investigated in a number of regions for the Kuroshio (Guo et al. 2006, Miyazawa et al. 2004) and for the Gulf Stream (Blanton et al. 1981, Brooks and Bane 1983). In our area of interest, in the microtidal Mediterranean Sea, process-oriented investigations have been performed on the curvated Catalan slope current along Ebro delta site's narrow shelf (Gjevik et al. 2002; Xing and Davies 2002) and of the Gulf of Lions (Flexas et al. 2002; Flexas et al. 2004). These previous investigations especially pointed the importance of the wind forcing, inertial motion and complex bathymetry on the cross-shelf fluxes in microtidal sea. The purpose of this paper is to examine the mesoscale slope current variability observed in the continental 
slope of the eastern Gulf of Lions during the ECOLOPHY cruises with help of numerical simulation. In our case, a realistic wind forcing was made available, allowing investigation of the origin of eddy and meander structure of the $\mathrm{NC}$ with help of a high-resolution model.

The Northern Current (NC) is the northern branch of the general cyclonic circulation in the western Mediterranean basin, where relatively fresh surface water flows from the Atlantic Ocean (Atlantic Water, hereafter called AW) through the Gibraltar Strait into the semi-enclosed Mediterranean Sea, to compensate for evaporation losses. This current results from the junction of the Western Corsican Current (WCC), flowing north-eastward from the Algerian Basin, and the Eastern Corsican Current (ECC) arising from the Tyrrhenian Sea through the Channel of Corsica (Astraldi and Gasparini, 1992). The NC is a slope current flowing along the coast from the Ligurian Sea up to the Balearic Sea. Several cruises performed over the two last decades have shown that this current exhibits a seasonal variability with maximum flux in winter, ranging from a minimum of $0.2 \mathrm{~Sv}\left(1 \mathrm{~Sv}=1.10^{6} \mathrm{~m}^{3} \cdot \mathrm{s}^{-1}\right)$ in summer to a maximum of $1.2 \mathrm{~Sv}$ in winter across a transect off Marseille (Lapouyade and Durrieu de Madron, 2001) and from $1 \mathrm{~Sv}$ to $1.6 \mathrm{~Sv}$ between 0 and $300 \mathrm{dbar}$ from autumn to summer off the city of Nice (Albérola et al. 1995). It is a wide (ca. $50 \mathrm{~km}$ ) and shallow (down to $250 \mathrm{~m}$ depth) current in summer; it becomes narrower (ca. $30 \mathrm{~km}$ ) and deeper (ca. $450 \mathrm{~m})$ in winter; with a maximum velocity near the surface $\left(30-50 \mathrm{~cm} \cdot \mathrm{s}^{-1}\right)$, then linearly decreasing with depth.

This current generally flows to the south of France, along the deepest half of the continental slope of the Gulf of Lions (GoL) where it bounds and controls the shelf circulation. Depending mainly on wind forcing conditions, it may intrude on 
the continental shelf, especially in the eastern, and sometimes in the central, parts of the gulf (Millot, 1979; Millot and Wald, 1980; Estournel et al, 2003; Petrenko, 2003). The complex GoL continental slope is intersected by a number of irregular canyons (Fig. 1). These irregularities, considering the potential vorticity conservation, can generate mesoscale current features, such as meanders, filaments and secondary eddies on the inner side of the NC (Flexas et al., 2002). Therefore, water exchanges across the GoL continental slope are influenced by mesoscale instabilities of the NC, and by strong northwestern (Tramontane) and northern (Mistral) continental winds, which generate classical oceanographic small-scale features such as coastal up- and down-wellings along coasts (Millot, 1979) and inertial motions (Petrenko, 2003). Water exchanges are also influenced by dense water cascading induced by wintertime continental winds (DufauJulliand et al., 2004; Guarracino et al., 2006). However this last process, acting with an interannual variability is not in the purpose of the present study.

\subsection{Evidence of mesoscale current variability}

The NC displays intense mesoscale variability, which mainly appears as meanders and anticyclonic eddies occurring at the jet edge over the upper continental slope, exhibiting different noticeable length scales. These meanders have a wide range of wavelengths (some 10 to $100 \mathrm{~km}$ ), phase speeds of 10 to 20 km.day $^{-1}$ (Albérola et al., 1995) and major variability occurs within a 2- to 10-day period. Durrieu de Madron et al. (1999) and Lapouyade and Durrieu de Madron (2001) observed a seasonal signal with stronger mesoscale variability in winter than in summer, when other authors (Taupier-Letage and Millot, 1986) reported significant mesoscale activity during an extended winter from December to May, highlighting a good correlation between maximum momentum energy in the NC 
and a high mesoscale variability. Although major mesoscale activity is usually assumed to occur in late autumn and decrease in late winter, meanders have been observed from satellite images throughout the whole year (Millot, 1999).

Current records obtained near the bottom of the GoL continental slope revealed that topographic waves propagate at a period of about 8 days with a mean phase speed of $11 \mathrm{~cm} \cdot \mathrm{s}^{-1}$, the bottom slope acting as a wave-guide (Millot, 1985). According to in situ data recovered off Nice during the PRIMO-0 (December 1990 - May 1991), PROLIG-2 and PROS-6 experiments (May - December 1985), in a location just upstream from the entrance of the GoL (Albérola et al., 1995; Sammari et al., 1995), two frequency ranges appeared in winter: a more energetic 10- to 20-day band and a weaker 3- to 6-day band. During the MATER HFF experiment (March - May 1997) current observations at 240-, 650- and 1230-m and hydrographic data showed that meanders occupied a large part of the water column (Flexas et al., 2002). From these data, two main peaks were observed with different characteristics: along-slope fluctuations with a 7-day period and isotropic fluctuations with a 3.5-day period. Using current measurements and analytical models, Flexas et al. (2002) proposed that the large NC meanders with a 10- to 40-day period and those with a 7-day period could be due to baroclinic instabilities. The case of the 3.5-day period fluctuations was investigated in detail in Flexas et al. (2004) who indicated that barotropic instability was one of the possible mechanisms (co-existing with baroclinic-type instabilities) responsible for such oscillations. According to Flexas et al. (2002), the 7- and 3.5-day period current fluctuations probably reflect propagating topographic Rossby waves (Pedlosky, 1979). 


\subsection{Present study}

The ECOLOPHY experiment is part of the French National AtmosphereOcean program (Programme National Atmosphere - Océan à Multiéchelles). This research project was initiated to improve the understanding of $\mathrm{NC}$ variability as a major process in water exchange across the GoL shelf. In order to investigate the seasonal and mesoscale variability of the NC, the ECOLOPHY experiments were conducted in spring and autumn 2005 in the southeastern part of the GoL, over the shelf-break (Fig. 1). This area is considered to be the generation zone for eddy and meander current structures of the NC (Flexas et al., 2002). The sampled zone was formed by an upstream coarse grid providing cross-NC measurements at the entrance of the GoL and by a downstream higher-resolution grid, located on the shelf-break, to capture fine eddy structures.

The objective of the present work is to examine the mesoscale variability based on moored ADCP current records, ship-borne hydrological and currents measurements, and drifting buoy trajectories. A high-resolution model was also used to investigate the origin of eddy and meander structure of the NC. Finally, a discussion of results and subsequent investigations are presented.

\section{Materials and methods}

\subsection{Observations}

The two ECOLOPHY experiments were conducted in the southeastern part of the GoL, in a first phase (hereafter called EXP-1), from May 28 to June 5, 2005 and in a second phase (EXP-2) from December 1 to 11, 2005. Hydrodynamic features were thus documented for different weather and stratification conditions. Hydrological data were collected using CTD (Conductivity Temperature Depth) and XBT (Expendable Bathythermograph) probes at stations indicated on Fig. 1. Vertical profiles of horizontal currents were measured along the R/V Tethys II 
track using an ADCP profiler mounted on its hull. Description of the circulation features was completed using Lagrangian drifter trajectories, providing long time series of current measurements in the NC. Moreover, two fixed moorings (called M1 and M2) were deployed on the shelf from May 28 to December 1, 2005 and again until June 19, 2006. These continuous measurements provided valuable information concerning the variability of currents over the upper slope.

\subsubsection{Drifter tracks}

During the two experiments, 24 surface floats anchored at 50 or $75 \mathrm{~m}$ depths were released off Cape Sicié, inside the NC vein. 16 buoys were launched on 3 consecutive legs during EXP-1 and 8 others on 2 legs during EXP-2. Surdrift (SC40 type during EXP-1 and SVP type during EXP-2) positions were collected using GPS then transmitted via Argos to the orbiting satellites. The validated space-time series of drifter locations were linearly interpolated over time to obtain the trajectories with a $1 \mathrm{~h}$ time-step. Release dates and locations are given in Table $\mathbf{1}$.

Lagrangian velocities were computed from drifting buoys successive positions. A Lanczos filter with a cutoff frequency of $40 \mathrm{hr}$ was applied on validated velocity data in order to remove inertial oscillations (periods of about $17.5 \mathrm{hr}$ ) and other shorter periods. Surdrifts are not exactly Lagrangian because the drag exerted on the surface buoy and on the cable linking the buoy to the deep drogue contributes to their displacement. However, this drag effect is negligible compared to the drag exerted on the drogue itself. Tests were also performed using acceleration values to detect possible loss of drogues or trawling. In such cases, trajectories were terminated. This detection of drogue loss is a crucial point because if a drogue breaks, the trajectory will reflect surface wind-induced currents and not depth currents. Surdrift lifetimes are given in Table 1. 


\subsubsection{Current data}

Current data were obtained in two different ways. First, vertical current profiles were collected from an ADCP current profiler (RDI broadband $150 \mathrm{kHz}$ ) mounted on the hull of the R/V Tethys II, along tracks shown in figure 1. Continuous measurements were made during all cruises that gave a quasi-synoptic view of the circulation over the entire water column. The time spend by the ship to performed each section is about $7 \mathrm{~h}$ for $\mathrm{T} 1$ and $\mathrm{T} 3$ and $5 \mathrm{~h}$ for $\mathrm{T} 2$. The chosen settings were: 60 cells, $4 \mathrm{~m}$ depth bins, 1-minute ensemble average, and bottom tracking when possible. ADCP data analysis was performed by the French INSU (Institut National des Sciences de l'Univers, http://saved.dt.insu.cnrs.fr) staff. The shallowest reliable measurement is at $10 \mathrm{~m}$ depth and the deepest one is at ca. 200 m.

Second, two Broadband RDI 75 kHz ADCP moorings called M1 and M2 were deployed on the bottom at depths of 400 and $200 \mathrm{~m}$, respectively, next to the shelf break, on the western flank of adjacent canyons' heads (Fig. 1). The settings used were: 50 cells and 30-minute ensemble averages for both moorings and $8 \mathrm{~m}$ depth bins for M1 and $4 \mathrm{~m}$ depth bins for M2. These moorings provided current measurements at given points from the end of May 2005 to June 2006.

\subsubsection{Hydrological data}

During the two ECOLOPHY cruises, 156 CTD stations or XBT casts were performed along three transects (see Fig. 1). The first hydrological network (EXP1) included 77 CTD and XBT stations (May 28 - June 5, 2005). The second hydrological network (EXP-2) comprised 79 CTD and XBT stations (December 1-11, 2005). This kind of measurement does not provide an exact synoptic view of hydrological features regarding the higher frequency variability of the NC. Nevertheless, reconstituted temperature, salinity and density fields along sections 
from hydrological measurements averaged over the duration of the surveys will be used to analyze its mean behavior.

\subsection{Numerical model}

Modeling was performed using the MARS-3D (3D hydrodynamic Model for Applications at Regional Scales) code developed at IFREMER (Lazure and Dumas, 2007). A description of the model configuration for the Northwestern Mediterranean Sea is given in André et al. (2005). Primitive equations were solved applying the Boussinesq approximation, hydrostatic equilibrium and incompressibility. This free-surface model, based on the proposal of Blumberg and Mellor (1987), uses an original semi-implicit and iterative time-step scheme allowing the simultaneous integration of internal and external modes on long time runs in a fast and conservative way.

Equations were discretized in finite differences on a staggered "C" grid as defined by Arakawa and Lamb (1977). A sigma-coordinate vertical transformation, locally refined near surface and bottom, is used. Attention has been paid to the formulation of the horizontal pressure gradient, and a fourth order scheme (Shchepetkin and McWilliams, 2003) was implemented. The vertical turbulent diffusion of momentum, heat and salt is computed from an algebraic relation (Pacanowsky, 1981) introducing a stratification effect through the local Richardson number. A Laplacian-type horizontal viscosity coefficient is computed from Smagorinsky's formulation (Smagorinsky, 1963) bounded by lower and upper limits (respectively equal to $1 \mathrm{~m}^{2} \cdot \mathrm{s}^{-1}$ and $200 \mathrm{~m}^{2} \cdot \mathrm{s}^{-1}$ ). Particular attention was paid here to the sharpness of density fronts using a TVD scheme (Harten, 1983) for heat and salt advection in combination with a second order Quick scheme (Leonard, 1979) for momentum advection. 


\subsubsection{Model configurations}

The initial coarse model configuration (hereafter called the NORMED configuration) computes the Northern Basin circulation with a $1.2 \mathrm{~km}$ horizontal grid and 30 vertical sigma layers. Its southern open boundary is located at $39.5^{\circ} \mathrm{N}$ between Spanish and Italian coasts. A finer grid model using a $400 \mathrm{~m}$ mesh size is then embedded in NORMED over the Gulf of Lions domain (Fig. 1). Details of this high resolution model configuration are described in Table 2.

\subsubsection{Initial and boundary conditions}

The MFS (Mediterranean Forecasting System) global Mediterranean model using data assimilation (Pinardi et al., 2003) provides initial state and boundary conditions for the NORMED model. The MFS model computes the whole Mediterranean Sea with a $3 \mathrm{~km}$ horizontal grid and 72 vertical levels with a $24 \mathrm{~h}$ time step. The output fields (temperature, salinity, current and sea surface elevation) are linearly interpolated on the NORMED grid. At the open sea boundary, the sea surface elevation is prescribed with a contribution of the prognostic interior solution. This method is known as the Flow Relaxation Scheme (FRS) proposed by Martinsen and Engedahl (1987). An upstream condition is applied to temperature and salinity scalar fluxes. This implies that the external fields are advected into the smaller domain during inflow situations only. Moreover, in a band of ten grid steps, temperature and salinity are relaxed toward the values obtained from the coarser grid model using a constant coefficient, thus introducing a time relaxation scale of approximately two days. Furthermore, on the same layer, a sponge condition using an exponential increase in momentum viscosity coefficients is applied along the open boundary in order to dampen potential numerical instabilities generated by the FRS. The same boundary conditions are applied to the eastern and southern boundaries of the nested GoL 
model located at $7.27^{\circ} \mathrm{E}$ and $41.66^{\circ} \mathrm{N}$, respectively. This zoom configuration was run over the two ECOLOPHY cruises after a 1-month spin-up modeling exercise. Potential difficulties in modeling may arise, due to the fact that the Northwestern Mediterranean Sea is highly sensitive to ocean-atmosphere exchanges. The use of a high-resolution atmospheric model is therefore essential, in order to take into account the orography effects on the wind fields and to depict as precisely as possible the strong variability of atmospheric fluxes in this area. Furthermore, land-sea temperature discontinuity which induces thermal breezes must be accurately modeled. For the present investigation, a regional atmospheric forcing computed with the MM5 ( $5^{\text {th }}$ generation PSU/NCAR mesoscale model) atmospheric model is used. This model provides three hourly radiative solar and long-wave fluxes, air temperature at the sea surface, humidity at $2 \mathrm{~m}$ and wind at $10 \mathrm{~m}$ heights on a $3 \mathrm{~km}$ grid. The wind stress, together with the latent and sensible heat fluxes, are calculated from the atmospheric parameters and from the modeled Sea Surface Temperature (SST), using the iterative bulk formulae based on the Monin-Obukhov similarity theory; see Geernaert (1990) for details.

\section{Results and discussion}

\subsection{ADCP moorings}

\subsubsection{Mean current and fluctuations}

Statistics are computed from current measurements obtained from M1 and M2 ADCP moorings over the whole recording period, and from positions of drogued Surdrift buoys that were neither trawled nor grounded and still in the GoL area (defined by a box comprised between $3-6^{\circ} \mathrm{E}$ and $41.5-43.5^{\circ} \mathrm{N}$ ). The inertial frequency band (ca. $17.5 \mathrm{hr}$ ), which is the major high frequency signal, is beyond 
the scope of this present study. Thereafter, time series were thus filtered with a low-pass Lanczos filter with a cut-off period of $40 \mathrm{hr}$.

The current ADCP measurements at $50 \mathrm{~m}$ depth, given in figure 2, show high variability. Ship-borne ADCP measurements along across-slope sections show that the NC core is characterized by velocities greater than $30 \mathrm{~cm} \cdot \mathrm{s}^{-1}$ at depths of $50 \mathrm{~m}$ in the summer (Fig. 13). It is also now well-established that the NC velocities are at their minimum during this season (Albérola et al., 1995). So, in keeping with this minimum criterion, figure 2a) which represents current measured in the main $\mathrm{NC}$ direction (SW-NE), shows that the core of the $\mathrm{NC}$ rarely reached the ADCP mooring, except in the winter, when the $\mathrm{NC}$ is known to be narrower and stronger. Velocities in the SW-NE direction remain negative, indicating that $\mathrm{ADCP}$ moorings are influenced by the $\mathrm{NC}$ edge. This is corroborated by the time-averaged mooring current measurements (Fig. 3a) which show that mean currents are mainly oriented southwestward. In the upper levels (50 and $100 \mathrm{~m}$ depths), the direction of the time-averaged currents are westsouthwestward, following the mean bathymetry, while the time-averaged currents follow local bathymetry closer to the bottom. The relatively large eccentricities of the variance ellipses (Fig. 3b), ranging from 0.68 to 0.84 for M1 and from 0.75 to 0.88 for M2, indicate that the current fluctuations are mainly rectilinear. When depth increases, the eccentricity of the variance ellipses also increases. This indicates that in the upper levels (depths of 50-100 m), fluctuations are more isotropic than at near-bottom levels, where current oscillations are strongly constrained in direction by the local bathymetry.

As reported in Table 1, mean Surdrift buoy velocities range from 8 to $24 \mathrm{~cm} \cdot \mathrm{s}^{-1}$ during the first three legs (EXP-1) and from 14.9 to $32 \mathrm{~cm} \cdot \mathrm{s}^{-1}$ during legs 4 and 5 (EXP-2). Hence, we note an increase in NC velocities between EXP-1 (late 
spring) and EXP-2 (late autumn and early winter). Moreover, no significant mean velocity differences are observed from these Surdrift buoy trajectories at depths between 50 and $75 \mathrm{~m}$. Velocities measured by ADCP moorings (at points M1 and M2) show that the mean current decreased from the surface to the bottom. For the M2 location, the mean velocity at $50 \mathrm{~m}$ is ca. $9.2 \mathrm{~cm}^{-1}{ }^{-1}$, and then decreases to 6.7 and $6.4 \mathrm{~cm} \cdot \mathrm{s}^{-1}$ at 100 and $150 \mathrm{~m}$ depths, respectively. For the M1 location, the same tendency is observed with a decrease in the mean velocity from $12.1 \mathrm{~cm} . \mathrm{s}^{-1}$ at $50 \mathrm{~m}$ to $4.6 \mathrm{~cm} \cdot \mathrm{s}^{-1}$ at $350 \mathrm{~m}$.

\subsubsection{Mesoscale variability of the NC}

The goal of this section is to define the mesoscale variability of the NC and to assess its origin. As an estimate of the mesoscale activity, the centered variance of the current is defined by $\left(\sigma_{\mathrm{u}}{ }^{2}+\sigma_{\mathrm{v}}{ }^{2}\right) / 2$ over a 10-day period (Fig. 4a M2; and Fig 4b M1) from ADCP mooring current measurements (Taupier-Letage and Millot, 1986). From these figures, it can be observed that mesoscale activity weakens with depth from $50 \mathrm{~m}$ to the bottom. These figures exhibit three interesting periods: (i) from October to December, (ii) from January to February and (iii) from April to May.

(i) From October to December the NC variability increases when the NC has been depicted as relatively wide and shallow (Albérola et al., 1995). This variability increase is especially observed at M2, at $50 \mathrm{~m}$ depth. Considering that this increase is not observed at M1 and that it is observed mostly at $50 \mathrm{~m}$ depth, it could be related to wind effects affecting only the upper part of the NC. Indeed, below, the NC flows independently of wind conditions, which could explain the similar variability at M1 and M2 sites. Wind velocity (Fig 5a and b) reveals the presence of southeastern winds in October and mid-November, which were potentially able to displace the NC northward shorewards. Moreover, in figure 5c, 
high wind variance values can be seen during November. In December, when the NC becomes deep and narrow with maximal current velocities (Albérola et al., 1995), mesoscale activity rapidly increased at all depths. The highest variance values are reached at the beginning of February.

(ii) The variability observed during January-February, both at M1 and M2, from $50 \mathrm{~m}$ down to $400 \mathrm{~m}$ depth, might indicate that the NC moves onshore, affecting entirely both M1 and M2. Moreover, this increase in the mesoscale variability is also associated with strong southeastern winds in January, and with high wind variance values. Then, in February the variance signal suddenly decreases until the beginning of March, a period when the current is known to weaken, becomes wider and shallower and is moved away from the coast (Albérola et al., 1995). These features are remarkably consistent with those previously obtained during PRIMO-0 (Albérola et al., 1995), PROGLI-2 and PROS-6 (Sammari et al., 1995) and DYOME (Taupier-Letage and Millot, 1986) experiments.

(iii) Finally, April and May show two main peaks. Compared to winter peaks, those occurring during April-May are more barotropic, in the sense that similar variability is recorded from 50 down to 300 and $400 \mathrm{~m}$ depth during May and April, respectively. This observation is particularly true at M1 location, possibly indicates that the NC is moved offshore and deepens. Hence, mesoscale current activity is well correlated with seasonal variability of the NC. Nevertheless, wind might also have a significant effect.

\subsubsection{Spectral analysis}

Kinetic energy spectra are computed from $1 \mathrm{hr}$ integration time series of currents collected with two ADCP moorings (named M1 and M2), using frequency-averaging (Mercier, 1991). The Number of averaged frequency is 5 or 
3 indicated by the confidence interval plotted in the top of figures $\mathbf{6}$. Currents were previously filtered out from the original time series with a low-pass Lanczos filter with a cut-off period of $40 \mathrm{hr}$.

Kinetic energy spectra computed from depth-averaged current measured by the two ADCP moorings are shown on figure 6a. These spectra correspond almost to the barotropic current oscillations. Energy peaks around 5.5-, 10- to 15- and 30day periods are observed for M2 and at 3.8-, 5- to 6.5-, 9-, 11.6- and 20- to 30-day periods for M1. Spectra are also computed at several depths to investigate vertical oscillation structure. These spectra reveal that the energy is higher in upper levels and decrease with depth. M1 (Fig. 6c) and M2 (Fig. 6b) peaks are rather similar, and two main frequency bands can be discerned: one from 3- to 5.3-day and a second from 9- to 15-day periods. Other peaks are also visible at periods equal to or greater than 21 days. These kinetic energy spectra seem to be relatively coherent in the vertical direction for M2, whereas for the M1 the behavior of variability is slightly different at the surface compared to deeper levels.

Kinetic energy spectra computed from depth-averaged modeled current at M1 and M2 are plotted on figure 7. Comparison with spectra computed from measured currents shows that energy of fluctuations is in the same range. Moreover, two main bands of fluctuation at mesoscale can also be distinguished: a first one from 2.7 to 7 day and a second one between 9 and 13 days.

Spectral analysis gives the orientations of the current ellipses and the principal axes at the energy peaks (Mercier, 1991). In figure 8, the only current ellipses corresponding to periods close to $11.6,5.4$ to 4.7 and 3.8 days for the M1 mooring, and 13.3, 5.3 and 3.3 to 3.7 days for $\mathrm{M} 2$, are plotted. These variance ellipses clearly show that current oscillations at 11 and 13 days are mainly 
oriented in the direction of the mean current, i.e. southwestward (Fig. 8a and 8b). At 5.3 days, for M2 (Fig. 8d) ellipses are also in the along-slope direction in the lower levels (100 and $150 \mathrm{~m}$ depths), but tend to be slightly in the cross-slope direction at $50 \mathrm{~m}$ depth. Fluctuations between 4.7- and 5.4-day periods, for M1, are oriented cross-slope (Fig. 8c). At the 3.8- to 3.4-day period, current oscillations are in the cross-slope direction in the upper levels with low eccentricities (0.63-0.68 at $100 \mathrm{~m}$ depth). These results show similarities for peaks from 3.3 to 5.4 days for both M1 and M2 locations which reinforce the conclusion done on spectral analysis that these peaks could all be considered as a single fluctuation band with similar characteristics. Fluctuations measured at M1 and M2 at periods ranging between 20 and 30 days (not shown), are strongly constrained in the along-slope direction with quite large ellipse eccentricities (between 0.950.99 for all levels). The most isotropic oscillations are measured at M1, where eccentricities reach 0.44 and 0.66 at periods of 6.3 and 8.9 days, respectively (not shown).

Hence, fluctuations measured at the 9-15 day-period band follow the local bathymetry at all depth. Fluctuation at the 3.3-5.4 days band tend to be oriented cross-slope in the upper layer $(<100 \mathrm{~m})$, turning along-bathymetry closer to the bottom. At M1 location, fluctuations are rather isotropic closer to the bottom and between the two major frequency bands. These behaviors can be due to the Ushape of the canyon head's topography at the M1 site location. These results are in accordance with previous measurements collected off the city of Nice by Sammari et al. (1995) who showed that from May to December, the 10- to 20-day band was recorded only in along-slope direction, whereas the 3- to 6-day period mainly appeared to be in the cross-slope direction. Nevertheless, during winter, the 10- to 20-day fluctuation band presented similar amplitudes in the along-shore and 
cross-shore components, suggesting a relationship to large mesoscale meanders. In both winter and spring, records from Albérola et al. (1995), the 3- to 6-day band fluctuations were also associated with meandering currents. Current measurements done over the continental slope of the GoL showed fluctuations at lower periods compared with those off Nice. Hence, Durrieu de Madron et al. (1999) found two fluctuation periods: one at 2 to 5 days and a second one at 7 to 10 days. These were associated with both along- and cross-slope components and were clearly associated with NC mesoscale meandering. Fluctuations of periods longer than 10 days occurred mostly in the along-slope direction.

\subsection{Measurements along sections}

\subsubsection{Hydrological features}

In this section, we examine density fields collected during EXP-1 through the three sections: T1, T2 and T3 (classified from east to west, from the eastern entrance of the gulf; see Fig. 1). Figure 9 shows potential temperature $(\theta)$, salinity and density distributions along sections, computed from vertical CTD profiles performed from May 29 to June 2, 2005. These sections evidenced well known water masses (Millot, 1990; Durrieu de Madron et al., 1990; Durrieu de Madron, 1994; Lapouyade and Durrieu de Madron, 2001): the water of Atlantic origin (AW) evidenced by relatively warm and fresh waters $\left(\theta>13.3^{\circ} \mathrm{C}\right.$ and $\left.\mathrm{S}<38.45\right)$ extending near the shelf-break, over the upper continental slope, from surface to approximately $300 \mathrm{~m}$ depth and the Levantine Intermediate Water (LIW) below, characterized by a relative maximum of $\theta$ and $S$ between 300 and $500 \mathrm{~m}$ depth close to the slope. These water masses are also visible on $\theta-\mathrm{S}$ diagram (Fig. 10). Along the T1 section (Fig. 9a), the AW vein is located to the north of $42.9^{\circ} \mathrm{N}$ down to a depth of about $300 \mathrm{~m}$. The isopycnals associated to the lower limit of 
AW (on the order of 29) show a strong slope in this location. In the T2 and T3 sections (Fig. 9b and 9c), the AW is visible to the north of $43.00^{\circ} \mathrm{N}$ and $42.9^{\circ} \mathrm{N}$, respectively. On the three sections, a low temperature cell is observed with $\theta<13.2^{\circ} \mathrm{C}$, at ca. $150 \mathrm{~m}$ depth. This cold water lens might be formed by cooling of the AW during winter, occurring upstream in the Ligurian Sea, and then advected below the surface. This water mass referred as the Winter Intermediate Water (WIW) by Millot (1999) is depicted as cold water in combination with low salinity values. In the southern part of the T1 and T3 transects (between 42.5 and $42.7^{\circ} \mathrm{N}$ ), the local increase in the slope of isotherms and isohalines need to interpreted with care. It may be a consequence of the radius of influence (ca. 15 $\mathrm{km}$ ) used in the interpolation procedure, which might be too small comparing to the CTD spacing at this location.

Figure 11 displays sections of 400m-grid resolution modeled density averaged from May 30 to June 2, 2005. The comparison of these results with the measurements collected during EXP-1 shows resemblances. Along section T1, the shape and depth of the 29 isopycnals are similar, but the density slope has a more southerly location in the model results (Fig. 11a) than in the hydrological measurements (Fig. 9a). The shift in the main isopycnal slope is also observed in section T3 (Fig. 11c). These shifts in the 29 isopycnal slopes are about $11 \mathrm{~km}$ for T1 and $20 \mathrm{~km}$ for T3. Moreover, near the shelf-break, modeled density is slightly higher than in the measurements. That is, isopycnals are deeper in the model results. All along section T2 (Fig. 11b), the density slope remains weak in the model outputs as well as in data.

Horizontal density fields measured at $50 \mathrm{~m}$ depth are shown in figure 12a. Comparison between measurements and the high-resolution model results 
averaged during the ECOLOPHY-1 period (Fig. 12b) reveals that the density fields are in the same range. Moreover the convex shape of the density front is in accordance with observations. Therefore, there is important difference along section $\mathrm{T} 1$ and $\mathrm{T} 3$. Indeed, considering the 28.8 isopycnal, the density front is fairly reproduced offshore. This lack might be due to the large scale forcing and initialization fields because it is also present in the MFS large scale modeled outputs.

This discrepancy is also visible comparing modeled and measured velocities at $50 \mathrm{~m}$ depth along the ship track (Fig. 12c and 12d). The NC, due to this density front, shows a more southerly position and a lower intensity than in observations. Along T1, a secondary vein of current, which is not observed from data field, is also modeled. Considering the modeled density field (Fig. 11a), this secondary vein would correspond to an adjustment of the isopycnal slope at $42^{\circ} 65^{\prime} \mathrm{N}$. This feature is due to a non-realistic off-shore re-circulation eddy which merges with the main core current between T1 and T3. Moreover, modeled NC along section T3 is not correctly oriented, indicating that current meanders are not correctly simulated in this area.

\subsubsection{Velocity features}

The geostrophic currents across transects are plotted in the top of figure $\mathbf{1 3}$. These currents are computed from density profiles along sections T1 and T3 with a reference level at the bottom depth, limited at $500 \mathrm{~m}$ depth. In the middle of figure 13, currents measured perpendicular to sections by hull-mounted ADCP are also shown. Comparison of the computed geostrophic component of the current with the observed one shows that the NC location and intensity are highly similar. In section T1 (Fig. 13a), the NC reached $45 \mathrm{~cm} \cdot \mathrm{s}^{-1}$ at $30 \mathrm{~m}$ depth and its width is about $30 \mathrm{~km}$. The width of the computed geostrophic current is about $35 \mathrm{~km}$. The 
maximum geostrophic current computed across section T3 (Fig. 13b) is greater than $45 \mathrm{~cm} . \mathrm{s}^{-1}$ on the surface. The measured current is of the same order but shows the highest intensity at ca. $50 \mathrm{~m}$ depth. From the hull ADCP measurements, we observe that the NC moves about $10 \mathrm{~km}$ between May 30 and June 1, 2005 along section T1, and between May 29 and June 2, 2005 along section T3. This temporal variability is not detected by CTD measurements because profiles collected during this 4-day period have been interpolated to plot these sections. Moreover, the CTD spacing that is larger than the internal radius of deformation also lead to a smoothing of the density field and geostrophic velocities. This could explain the wider horizontal extent of the computed geostrophic current. Nevertheless, since the computed density currents and measurements are quite similar, it is clear that the $\mathrm{NC}$ is mainly in geostrophic equilibrium. The NC velocity and its width give a Rossby number $\left(R_{0}=U / f L\right)$ ranging between 0.11 and 0.16 . These $R_{0}$ values are close to those previously reported in the literature $(0.1$ in Sammari et al. (1995) and 0.16 in Flexas et al. (2002). A secondary geostrophic current is also computed in section T3 at ca. $42.62^{\circ} \mathrm{N}$. This current is an artifact due to the interpolation method used to compute density fields (see previous section). Transport of the NC across the three sections, computed from geostrophic velocities down to a depth of $500 \mathrm{~m}$, is $1.41,0.92$ and $1.18 \mathrm{~Sv}$, respectively.

Velocity features measured with hull-mounted ADCP perpendicular to section $\mathrm{T} 1$ and $\mathrm{T} 3$ are also compared to model outputs. Hence, modeled currents were spatially and temporally interpolated at the measured points. Comparisons, shown on figure 13, indicate that the modeled NC vein is located $15 \mathrm{~km}$ to the south compared to the actual measurements. This is in agreement with density fields 
(section 3.2.1). This flaw of the model simulation might be due to bathymetric effect through horizontal turbulence and vertical pressure gradient computation, which are not correctly evaluated in the model. The NC is simulated with realistic width and intensity despite the fact that the latter is slightly underestimated. Another difference is that Vessel-mounted ADCP profile along T1 presents high variability in the first $20 \mathrm{~m}$ of the water column, whereas model output shows an absence of velocity. This is due to an over-estimation of the wind effect on surface layer. Nevertheless, a mixed surface layer of about $15 \mathrm{~m}$ depth is measured. Below, NC's asymmetrical depth pattern, which has been attributed to wind-induced surface circulation (Dufau-Julliand et al., 2004) is reproduced by the model.

\subsection{Drogued-buoy trajectories}

Drifter trajectories provide information on the current at 50 and $75 \mathrm{~m}$ depths over the slope of the GoL and in the shelf. Five different deployments were performed (Table 1): three legs during EXP-1 (at the end of spring 2005) and two during EXP-2 (at the end of autumn 2005). It is clear on figure 14 that buoys tend to flow southwestward along the continental slope. Nevertheless, it is possible to distinguish two kinds of trajectories: a first one flowing over the upper slope up to the $1000 \mathrm{~m}$ isobath as during legs 2 and 4 (Fig. 14a and 14c), and a second one flowing over the lower slope between the 1000 and $2000 \mathrm{~m}$ isobaths (legs 3 and 5 on figures $\mathbf{1 4 b}$ and $\mathbf{1 4 d}$ ).

Here, we will describe the trajectories in the eastern part of the gulf, corresponding to the ECOLOPHY field campaign zone. Trajectories of buoys launched during the second deployment (Fig. 14a bis) show a number of small- 
scale anticyclonic eddies, with a scale of a few kilometers. This circulation is due to the creation of vorticity behind the Cape Sicié (located on figure 1). During the third buoy deployment, trajectories are observed rather homogeneous (Fig. 14b). They first flow southwestward and then are oriented northwestward before being guided by the slope. This kind of trajectory is characteristic of an upwelling circulation, which is known to occur south of Cape Sicié (André et al. 2005). Indeed, there is a storm with strong northwesterly winds (up to $15 \mathrm{~m} . \mathrm{s}^{-1}$ on July 1, Fig. 15a) from June 30 to July 2, 2005. This type of wind produces an offshore current in upper water levels compensated by an upwelling of waters from below. Such upwellings can persist during several days after the wind stops, explaining the southwestward circulation up to July 4. Then the wind weakens and changes to the east leading buoys toward the northwest. In figure $\mathbf{1 4 b}$, the ' $3 b$ ' buoy trajectory shows an intrusion of slope water onto the shelf at its eastern entrance in the Cassis Canyon (Fig. 1). Indeed, when stratification is strong enough with a shallow pycnocline, as it the case here, part of the NC can follow the eastern coast of the gulf and intrudes into the shelf (Echevin et al., 2003). Furthermore, this phenomenon is reinforced in the case of weak northeasterly winds (Petrenko et al., 2005; Petrenko, 2003). This buoy is then advected eastward by a coastal current generated during the upwelling relaxation. During the fifth buoy deployment in late autumn (Fig. 14d), trajectories of the four Surdrifts are identical on the eastern part of the gulf as far as $5^{\circ} 17^{\prime}$ 'E where the buoy ' $5 \mathrm{a}$ ' moves toward the upper slope, whereas the other ones follow the lower slope. Northeasterly winds blow over the extreme east of the gulf, between December 9 and 10, 2005 (Fig 15b). The corresponding model outputs clearly show a northward current at about $5,15^{\circ} \mathrm{E}$. Hence the buoy ' $5 \mathrm{a}$ ' is advected toward the upper slope and then is advected westward by a secondary flow visible at $43^{\circ} \mathrm{N}$. 
In this section, we describe the buoy trajectories in the whole GoL domain. Figure 14a clearly shows anticyclonic eddy trajectories over the shelf-break for buoys named: '2b', '2d', '2f' and '2g'. Centered at 4²0'E and at $3^{\circ} 50^{\prime} \mathrm{E}$, these mesoscale eddies have a diameter of a few dozen kilometers. Ertel Potential Vorticity (EPV) anomaly is computed as:

$$
\delta(E P V)=\frac{N^{2}}{g}(f+\zeta)-\frac{N_{0}^{2} f_{0}}{g}
$$

where $f$ is the coriolis frequency, $\zeta$ the relative vorticity, $g$ the gravity and $N$ the Brunt-Vaisala frequency. EPV is conserved for non-dissipative and adiabatic motion, making this a useful tool for following water particles (Buongiorno Nardelli et al., 2001). On June 20 , the ' $2 \mathrm{~g}$ ' buoy left the $\mathrm{NC}$ at $4^{\circ} \mathrm{E}$. This northward motion is clearly noticeable in the center part of the GoL's slope $\left(4^{\circ} \mathrm{E}-\right.$ $42^{\circ} 42^{\prime} \mathrm{N}$ ) on the modeled EPV and velocity fields at $50 \mathrm{~m}$ depth (indicated by letter $\mathbf{F}$ on Fig. 16a). This motion is associated with $\mathrm{NC}$ filaments which drive slope water northward. A few days later, this buoy is trapped by a weak countercurrent, which drives water eastward. Indeed, on figure 17, an eastward current with velocities lower than $10 \mathrm{~cm} . \mathrm{s}^{-1}$ is observed over the shelf-break in the whole water column. On June 29 (Fig. 16b), an anticyclonic eddy is formed in the western part of the continental slope at about $3^{\circ} 50^{\prime} \mathrm{E}-42^{\circ} 30^{\prime} \mathrm{N}$ (indicated by letter E). EPV field shows that a part of the $\mathrm{NC}$ is driven westward by this mesoscale feature while the main current is oriented southward. Furthermore, the field computed on June 29 (Fig. 16b) reveals a NC meander which is also described by the ' $2 \mathrm{~g}$ ' buoy. Hence, these EPV maps show eddies and meanders which drive drifter buoys. Therefore, the simulation realistically reproduces these mesoscale features of the current. 
During the fifth deployment (Fig. 14d), the '5a' buoy flows along the upper continental slope between the 200 and $500 \mathrm{~m}$ isobaths as far as the $4^{\circ} 10^{\prime} \mathrm{E}$ longitude, where it penetrates into the shelf. This kind of circulation was detected during heterogeneous winds due to adjacent northern (Mistral) and a northwestern (Tramontane) wind situation inducing a strong wind curl, which involves a cyclonic circulation in the western part of the GoL and an anticyclonic circulation in the northern part, driving water northward (Estournel et al., 2003). These heterogeneous winds take place from December 16 to 20, 2005 (Fig 15c). Although gyres are not as obviously observed as in the theoretical simulations performed by Estournel et al. (2003), a northwestward current is visible in the center of the gulf (at ca. $4^{\circ} 15^{\prime} \mathrm{E}$ ). Then, a Tramontane regime occurs, which induces cyclonic circulation in the western part of the gulf. Thus, drifter ' $5 \mathrm{a}$ ' flows along the GoL coasts, and continues towards the Catalan continental shelf. Behind Cape Creus there is an anticyclonic eddy, apparent in both figure 16b and figure 14d. This feature is due to the creation of vorticity behind the Cape similar to that observed past Cape Sicié.

\section{Conclusions}

The one-year data set collected over the upper continental slope of the Gulf of Lions during the ECOLOPHY experiment allows us to complement the description of the Northern Current mesoscale variability. A high-resolution hydrodynamic model (400 m grid size) is used to better understand NC mesoscale features, such as meanders, anticyclonic eddies and filaments forming over the shelf-break as revealed by Surdrift buoy trajectories.

Current measurements provided by ADCP moorings clearly show the southwestward drift of the NC along the slope. Although the current core rarely reaches the moorings themselves, they are influenced by the NC edge. The current 
fluctuations near the surface and at mid-depth are principally oriented along the main slope direction. Near-bottom current fluctuations are strongly constrained by the local bathymetry.

The mesoscale activity of the NC displays an annual maximum in winter for all depths, decreasing toward the bottom, in agreement with previous observations. This maximum of current variance is correlated with maximum NC flux. A secondary maximum occurs in autumn at $50 \mathrm{~m}$ depth, associated with strong southeasterly gusts. Spectral analyses reveal current oscillations at several frequencies ranging between 30 and 3 days. Previous studies off Nice established that 2 frequency bands can be distinguished: a first one at 10 to 20 days (corresponding to 7 to 10 days over the GoL's slope) and a second one at 3 to 6 days (2 to 5 days); both of them being associated with Northern Current meandering. Flexas et al. (2002) also found two bands of mesoscale activity centered at 7 and 3.5 days, off Marseilles. The present study corroborates previous observations. Indeed, two main frequency bands are observed: a first from 2.7 to 7 day and a second between 9 and 13 days. Current ellipses show that current oscillations at periods longer than 10 days are mainly oriented in the direction of the mean current. At shorter periods, in the 6.3- to 8.9-day period-band, fluctuations prove to be mainly isotropic. In the 3.3- to 5.4-day period-band, fluctuations are cross-slope, at least in the upper levels. Closer to the seafloor, these current fluctuations are often directed along the local bathymetry. These low-period bands were previously associated with $\mathrm{NC}$ mesoscale meandering.

Hydrological data allows us to distinguish the different water masses present in the first $500 \mathrm{~m}$ as the AW at surface (up to $300 \mathrm{~m}$ ) and WIW at subsurface (at about $150 \mathrm{~m}$ depth). The density gradient between AW and open sea water is the major driving mechanism of the Northern Current, which remains in quasi- 
geostrophic equilibrium. Comparisons of in situ density and current data with a high-resolution model (400 m horizontal grid) show the overall ability of the model to reproduce the major NC characteristics. However, some differences are detected concerning the position of the density front, and of the NC which appears to be roughly located $15 \mathrm{~km}$ south from actual measurements.

The combined analyses of drifter trajectories and modeling results revealed several mesoscale processes, such as:

- Wind-induced upwelling off Cape Sicié which drives the NC southwestward, generally followed by an intrusion of slope water onto the eastern part of the shelf during relaxation, as previously evidenced by Millot and Wald (1980);

- Formation of anticyclonic mesoscale NC eddies and filaments over the upper continental shelf, due to current instabilities. Slope water is then driven northward over the shelf-break, before being advected by an eastward countercurrent and finally comes back to the main current. These features were already observed on Sea Surface Temperature satellite images by Flexas et al. (2002);

- A northward current, in the center part of the shelf, due to the simultaneous occurrence of Mistral and Tramontane winds, inducing cyclonic and anticyclonic circulations, respectively, in the western and in the eastern part of the gulf, as already pointed out by Estournel et al. (2003).

This first interpretation of the ECOLOPHY measurements using model results showed that mesoscale current features over the shelf-break are also modeled. Nevertheless, numerical modeling need to be validated, especially concerning initial vorticity and separation from the coast in Cape Sicié site to better understand the discrepancies observed in the modeled trajectory on this slope 
current. Then, the origin of the NC mesoscale variability over the continental slope, which has been related to barotropic/baroclinic instabilities, will be investigate in more detail using this model configuration for different test cases to especially examine effects of the bathymetry and wind forcing. Moreover, the study of the NC mesoscale variability will be completed with recent measurements in order to asses the inter-annual variability of mesoscale activity.

Acknowledgments: We are grateful to the Provence-Alpe-Côte d'Azur Region and the CNRS-INSU through the PNEC and PATOM national programs for their financial support. The authors thank Alexandre Allou and Jean-Luc Devenon of the Marseille Oceanographic Center (CMO) for providing experimental data. We also thank the two anonymous referees for their constructive comments. 


\section{Figure captions}

Figure 1: Geographic and bathymetric map of the Gulf of Lions. Isobaths at 100, 200, 500, 1000 and $2000 \mathrm{~m}$ are given. The ECOLOPHY experimental area, hydrological stations, mooring positions and main transects are indicated.

Figure 2: Time series of filtered $50 \mathrm{~m}$ depth velocity measured by M1 (gray line) and M2 (black line) ADCP moorings in the along-slope (up) and the cross-slope directions (down).

Figure 3: Time-averaged currents (a) and variance ellipses of low-pass (period> $40 \mathrm{~h}$ ) current series (b) measured by M1 (right) and M2 (left) ADCP moorings, from May 29, 2005 to June 19, 2006.

Figure 4: Current variance defined by $\left(\sigma_{\mathrm{u}}{ }^{2}+\sigma_{\mathrm{v}}{ }^{2}\right) / 2$ as an estimate of mesoscale activity, computed over 10 days for (a) mooring M2 and (b) mooring M1.

Figure 5: Time series of wind velocities modeled with MM5 in the mooring area along the (a) zonal and (b) meridian directions and (c) wind variance computed over one month.

Figure 6: Kinetic energy spectra. (a) depth-averaged current, (b) mooring M2 and (c) mooring M1 at different depths.

Figure 7: Kinetic energy spectra of modeled depth-averaged current.

Figure 8: Variance ellipses of current series measured by ADCP moorings, from May 29, 2005 to June 19, 2006 filtered in the frequency band of $40 \mathrm{hr}$ for (left) mooring M1 and (right) mooring M2. Periods (days) given in figure titles correspond to energy peaks classified from upper to lower levels.

Figure 9: Temperature, salinity and density from CTD measurements collected from May 29 to June 2, 2005 through sections (a) T1, (b) T2 and (c) T3. 
Figure 10: Theta-S diagram from CTD measurements collected from May 29 to June 2, 2005 through sections $\mathrm{T} 1, \mathrm{~T} 2$ and $\mathrm{T} 3$.

Figure 11: Density from MARS-3D model results averaged over May 29 to June 2, 2005 through sections (a) T1, (b) T2 and (c) T3.

Figure 12: Density measured (a) during EXP-1 and hull-mounted ADCP measurements (c) from May 31 to June $1^{\text {st }}, 2005$ at $50 \mathrm{~m}$ depth. Time-averaged MARS-3D modeled density (b) and interpolated modeled velocities (d) at $50 \mathrm{~m}$ depth.

Figure 13: Geostrophic current computed from CTD density profiles (top); current measured by hull-mounted ADCP (middle) and corresponding modeled current (bottom) perpendicular to sections T1 (a) and T3 (b).

Figure 14: Anchor-depth buoy trajectories. Isobaths at 100, 200, 500, 1000 and $2000 \mathrm{~m}$ are given. Depth, position, mean speed, starting and ending date are given in Table 1.

Figure 15: Modeled wind (top) and velocities averaged over $100 \mathrm{~m}$ depth (bottom) on (a) July 1, (b) 10 and (c) December 18, 2005.

Figure 16: Modeled Ertel potential vorticity (EPV) and velocity fields at $50 \mathrm{~m}$ depth on (a) June 20 and (b) June 29, 2005. Isobaths at 100, 200, 500, 1000 and $2000 \mathrm{~m}$ are given. Letters E and F indicate, respectively the position of filament and anticyclonic eddy structure.

Figure 17: Modeled zonal velocity along section represented on Fig. 17 on June 23, 2005.

\section{Table caption}

Table 1: Surdrift buoy deployments during ECOLOPHY experiments. $T$ is the total operating time (days) and $V$ is mean scalar speed $\left(\mathrm{cm}^{-1} \mathrm{~s}^{-1}\right.$.

Table 2: Parameters of the high resolution model (ZOOM) configuration. 


\section{References}

Albérola, C., Millot, C. and Front, J., 1995. On the seasonal and mesoscale variabilities of the Northern Current during the PRIMO-0 experiment in the western Mediterranean Sea. Oceanologica Acta, 18: 163-192.

André, G., Garreau, P., Garnier, V. and Fraunié, P., 2005. Modelled variability of the sea surface circulation in the North-western Mediterranean Sea and in the Gulf of Lions. Ocean Dynamics, 55: 294-308.

Astraldi, M. and Gasparini, G.P., 1992. The seasonal characteristics of the circulation in the North Mediterranean Basin and their relationship with the atmospheric-climatic conditions. Journal of Geophysical Research. C. Oceans, 97(6): 9531-9540.

Arakawa, A. and Lamb, V.R., 1977. Computational design of the basic dynamical process of the UCLA General Circulation Model, Methods in Computational Physics. Academic Press, pp. $173-265$.

Blanton, J.O., Atkinson, L.P., Pietrafesa, L.J. and Lee, T.N., 1981. The intrusion of Gulf Stream water across the continental shelf due to topographically-induced upwelling. Deep Sea Research, 28(4): 393-405.

Blumberg, A.F. and Mellor, G.L., 1987. A description of a three-dimensional coastal ocean circulation model. In: N.S. Heaps (Editor), Three-dimensional Coastal Ocean Models. Coastal and Estuarine Sciences. American Geophysical Union, Washington, D.C., pp. 1-16.

Brooks, D.A. and Bane, J.M., 1983. Gulf Stream meanders off North Carolina during winter and summer 1979. Journal of Geophysical Research, 88: 4633-4650.

Buongiorno Nardelli, B., Santoleri, R. and Sparnocchia, S., 2001. Small mesoscale features at a meandering upper-ocean front in the western Ionian Sea (Mediterranean Sea): Vertical motion and potential voirticity analysis. Journal of Physical Oceanography, 31(8): 2227-2250.

Dufau-Julliand, C., Marsaleix, P., Petrenko, A. and Dekeyser, I., 2004. Three-dimensional modeling of the Gulf of Lion's hydrodynamics (northwest Mediterranean) during January 1999 (MOOGLI3 experiment) and late winter 1999: Western Mediterranean Intermediate Water's (WIW's) formation and its cascading over the shelf break. Journal of Geophysical Research, 109: C11002. 
Durrieu de Madron, X., Nyffeler, F., and Godet, C.H., 1990. Hydrographic structure and nepheloid spatial distribution in the Gulf of Lions continental margin. Continental Shelf Research, 10, 915-929.

Durrieu de Madron, X., 1994. Hydrography and nepheloid structures in the Grand-Rhône canyon. Continental Shelf Research, 14, 457-477.

Durrieu de Madron, X., Radakovitch, O., Heussner, S., Loye-Pilot, M.D. and Monaco, A., 1999. Role of the climatological and current variability on shelf-slope exchanges of particulate matter: Evidence from the Rhone continental margin (NW Mediterranean). Deep Sea Research Part I: Oceanographic Research Papers, 46(9): 1513-1538.

Echevin, V., Crepon, M. and Mortier, L., 2003. Interaction of coastal current with a Gulf: Application to the shelf circulation of the Gulf of Lions in the Mediterranean Sea. Journal of Physical Oceanography, 33: 188-206.

Estournel, C., Durrieu de Madron, X., Marsaleix, P., Auclair, F., Julliand, C. and Vehil, R., 2003. Observation and modelling of winter coastal oceanic circulation in the Gulf of Lion under wind conditions influenced by the continental orography (FETCH experiment). Journal of Geophysical Research, 108(C3): 8059.

Flexas, M.M., Durrieu de Madron, X., Garcia, M.A., Canals, M. and Arnau, P., 2002. Flow variability in the Gulf of Lions during the MATER HFF experiment (March-May 1997). Journal of Marine Systems, 33-34: 197-214.

Flexas, M.M., Heijst, G.J.F.v., Jordà, G. and Sánchez-Arcilla, A., 2004. Numerical simulation of barotropic jets over a sloping bottom: Comparison to a laboratory model of the Northern Current. Journal of Geophysical Research, 109: C12039.

Geernaert, G.L., 1990. Bulk parameterizations for the wind stress and heat fluxes. In: G.L. Geernaert and W.J. Plant (Editors), Surface waves and fluxes. Kluwer Academic, Dordrecht.

Gjevik, B., Moe, H. and Ommundsen, A., 2002. Idealized model simulations of barotropic flow on the Catalan shelf. Continental Shelf Research, 22(2): 173-198.

Guo, X., Miyazawa, Y. and Yamagata, T., 2006. The Kuroshio onshore intrusion along the shelf break of the East China Sea: The origin of the Tsushima warm current. Journal of Physical Oceanography, 36: 2205-2331.

Harten, A., 1983. High resolution schemes for hyperbolic conservation laws. Journal of Computational Physics, 49(3): 357-393. 
Lapouyade, A. and Durrieu de Madron, X., 2001. Seasonal variability of the advective transport of particulate matter and organic carbon in the Gulf of Lion (NW Mediterranean). Oceanologica Acta, 24(3): 295-312.

Lazure, P. and Dumas, F., 2007. An external-internal mode coupling for a 3D hydrodynamical model for applications at regional scale (MARS3D). Advances in Water Resources, In press.

Leonard, B.P., 1979. A stable and accurate convective modelling procedure based on quadratic upstream interpolation. Comp. Methods Appl. Mech. Eng., 19: 59-98.

Martinsen, E.A. and Engedahl, H., 1987. Implementation and testing of a lateral boundary scheme as an open boundary condition in a barotropic ocean model. Coastal Engineering, 11(5-6): 603627.

Mercier, E., 1991. Traitement du signal et méthodes d'observation en océanographie physique. IFREMER, $113 \mathrm{pp}$.

Middleton, J.F. and Cirano, M., 1999. Wind-Forced Downwelling Slope Currents: A Numerical Study. Journal of Physical Oceanography, 29(8): 1723-1743.

Millot, C., 1979. Wind-induced upwellings in the Gulf of Lions. Oceanologica Acta, 2: 261-274.

Millot, C. and Wald, L., 1980. The effect of Mistral wind on the Ligurian current near Provence. Oceanologica Acta, 3(4): 399-402.

Millot, C., 1985. Evidence of several-day propagation wave. Journal of Physical Oceanography, 15(3): 258-272.

Millot, C., 1990. The Gulf of Lions' hydrodynamics. Continental Shelf Research, 10: 885-894.

Millot, C., 1999. Circulation in the Western Mediterranean Sea. Journal of Marine Systems, 20(14): 423-442.

Miyazawa, Y., Guo, X. and Yamagata, T., 2004. Roles of mesoscale eddies in the Kuroshio paths. Journal of Physical Oceanography, 34: 2203-2222.

Mysak, L.A., Johnson, E.R. and Hsieh, W.W., 1981. Baroclinic and barotropic instabilities of coastal currents. J. Phys. Oceanogr., 11: 209-230.

Pacanowsky, R.C. and Philander, S.G.H., 1981. Parameterization of the vertical mixing in the numerical models of tropical oceans. Journal of Physical Oceanography, 11: 1443-1451.

Pedlosky, J., 1979. Geophysical fluid dynamics. Springer-Verlag, 710 pp. 
Petrenko, A., Leredde, Y. and Marsaleix, P., 2005. Circulation in a stratified and wind-forced Gulf of Lions, NW Mediterranean Sea: in situ and modeling data. Continental Shelf Research, 25(1): 7-27.

Petrenko, A.A., 2003. Variability of circulation features in the Gulf of Lion NW Mediterranean Sea. Importance of inertial currents. Oceanologica Acta, 26(4): 323-338.

Pinardi, N. et al., 2003. The Mediterranean ocean forecasting system: first phase of implementation (1998-2001). Annales geophysicae. Atmospheres, hydrospheres and space sciences, 21(1): 3-20.

Sammari, C., Millot, C. and Prieur, L., 1995. Aspects of the seasonal and mesoscale variabilities of the Northern Current in the western Mediterranean Sea inferred from the PROLIG-2 and PROS-6 experiments. Deep-Sea Research 1, 42(6): 893-917.

Smagorinsky, J., 1963. General circulation experiments with the primitive equations.1-The basic experiment. Monthly Weather Review, 91: 99-165.

Shchepetkin, A.F. and McWilliams, J.C., 2003: A method for computing horizontal pressuregradient force in an ocean model with a non-aligned vertical coordinate. J. Geophys. Res. 108, 3090.

Taupier-Letage, I. and Millot, C., 1986. General hydrodynamic features in the Ligurian Sea inferred from the DYOME experiment. Oceanologica Acta, 9(2): 119-131.

Xing, J. and Davies, A.M., 2002. Influence of shelf topography upon along shelf flow and across shelf exchange in the Ebro Delta. Continental Shelf Research, 22: 1447-1475. 
Figure 2

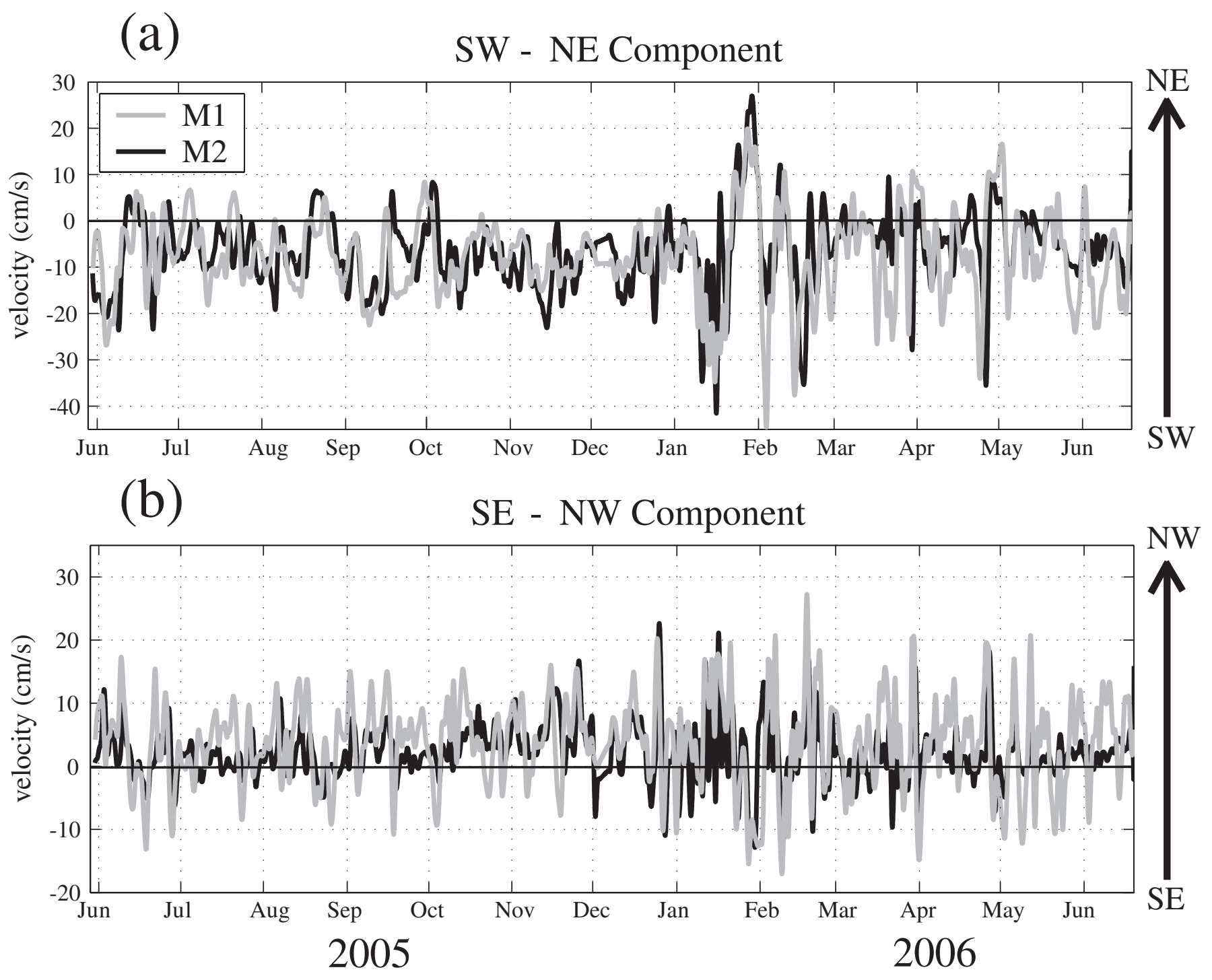


(a)
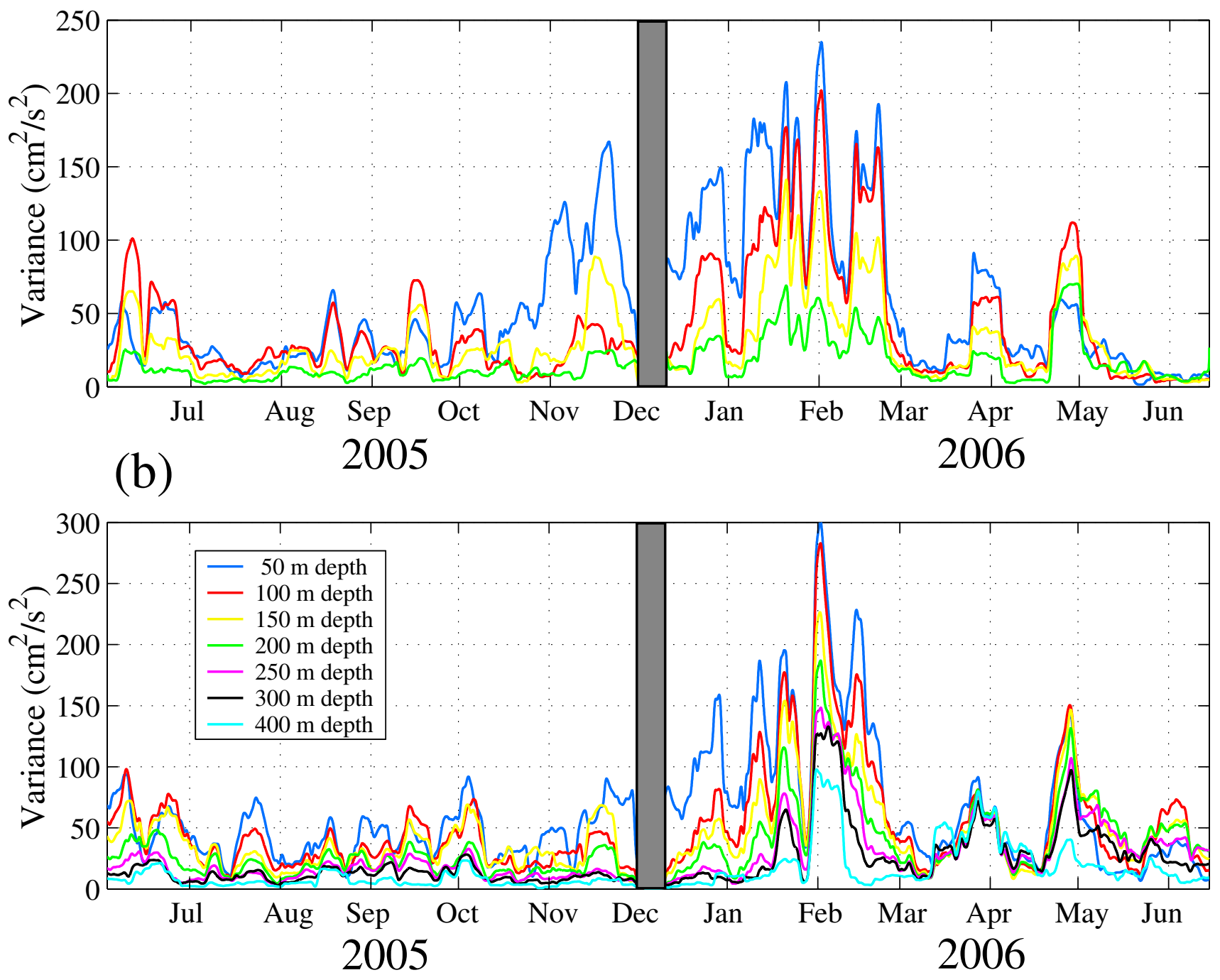
Figure 6

(a)

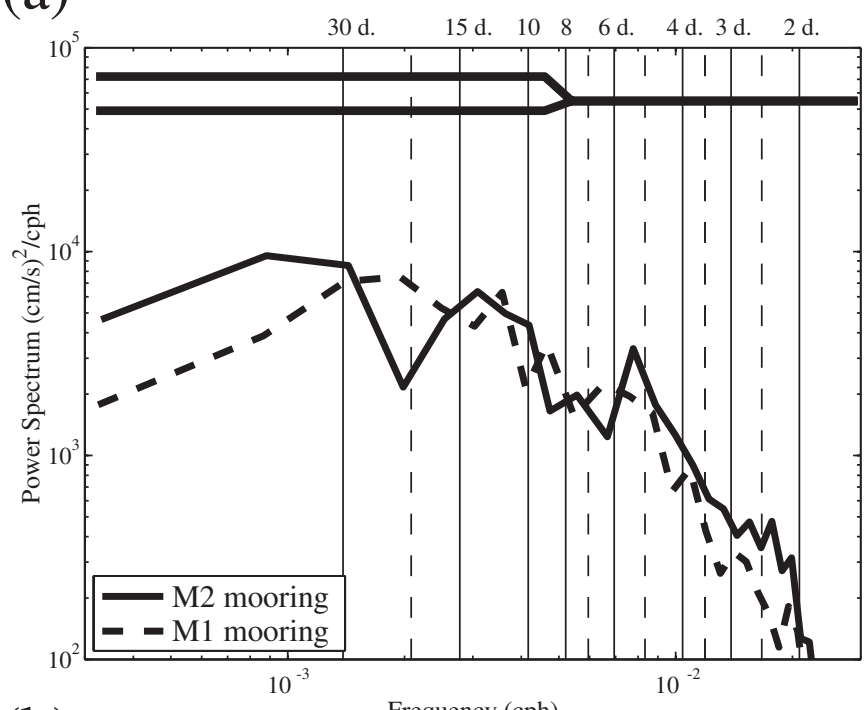

(b)

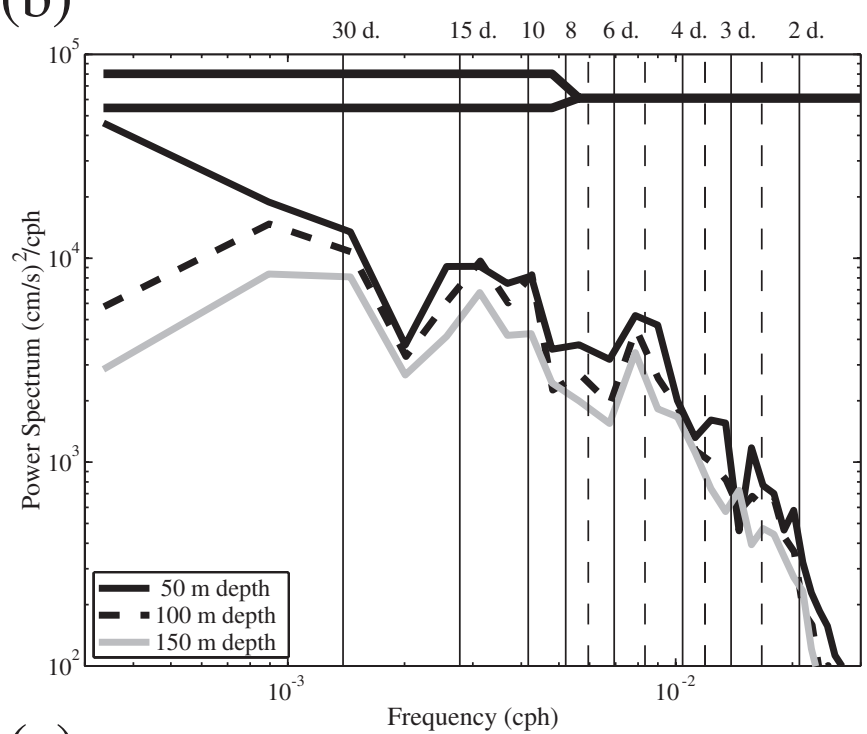

(c)
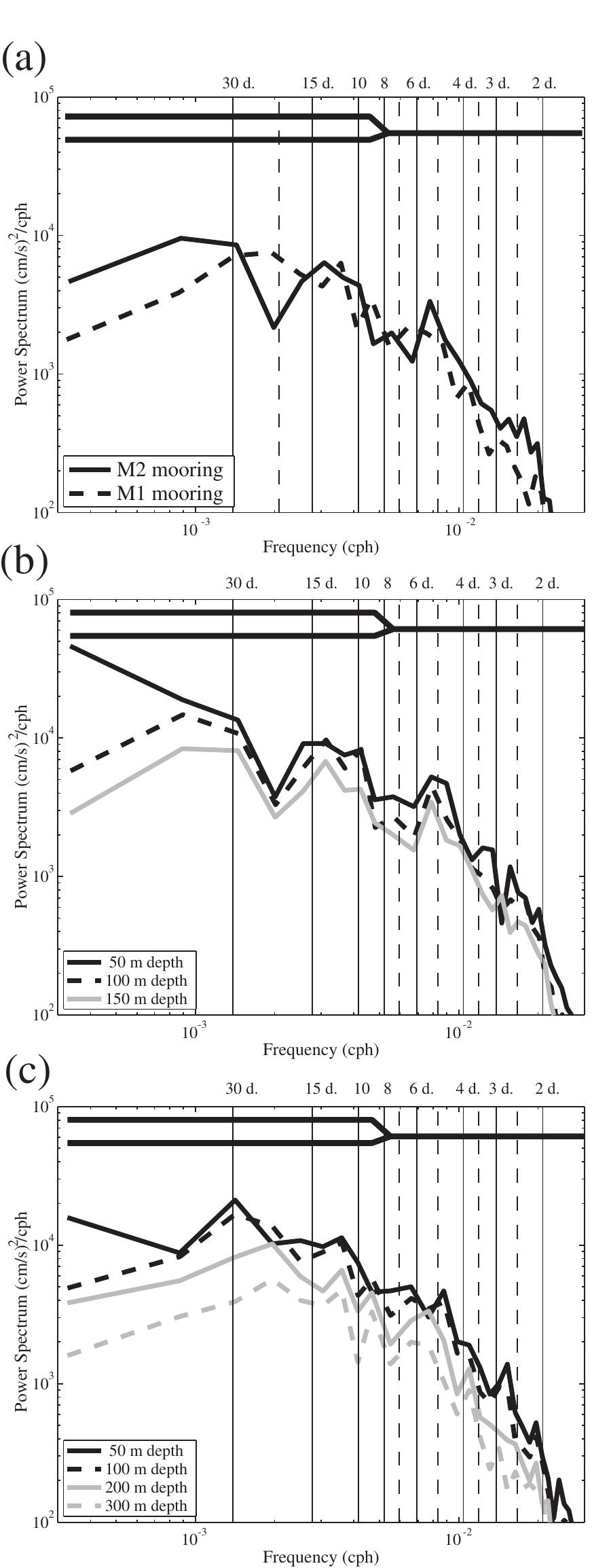


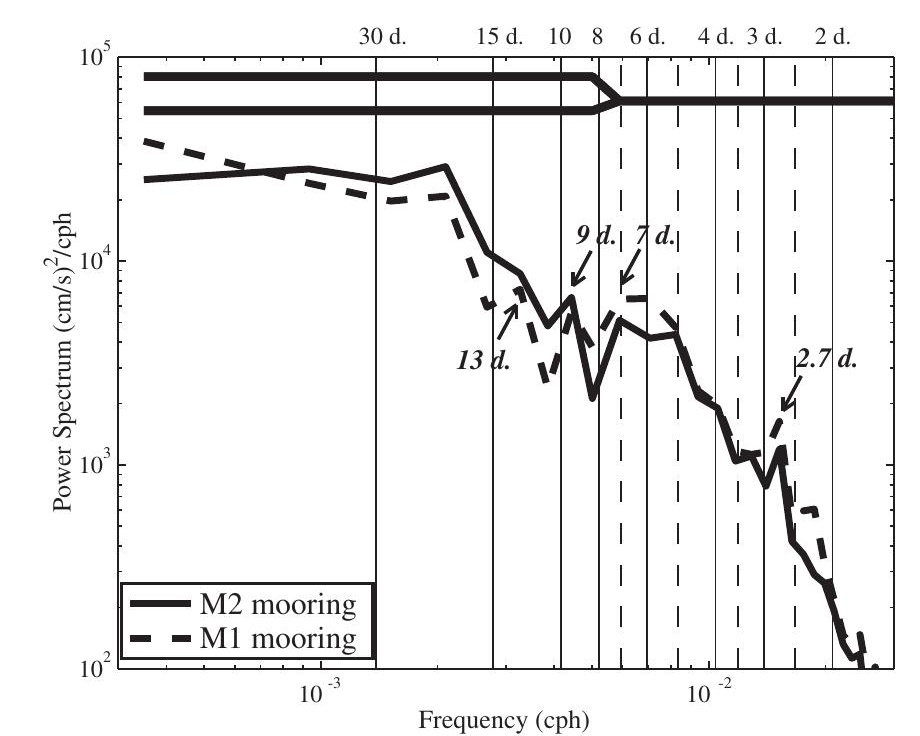

Figure 7 
(a)

11.6 days

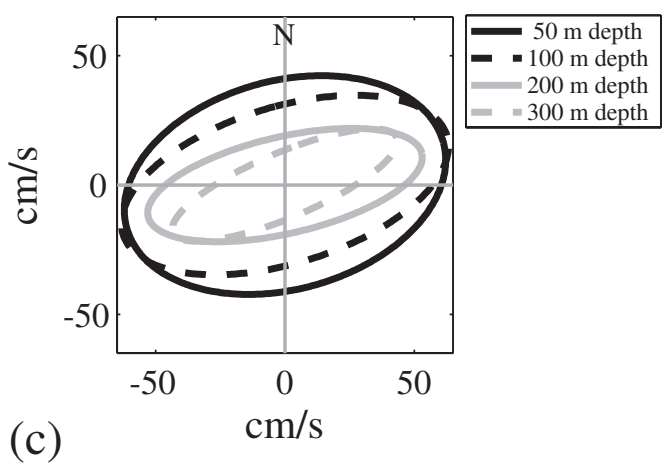

(c)

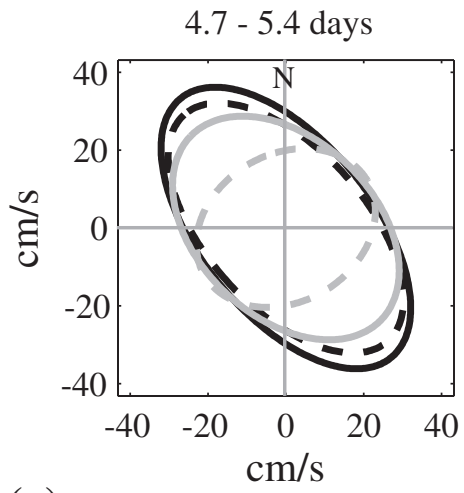

(e)

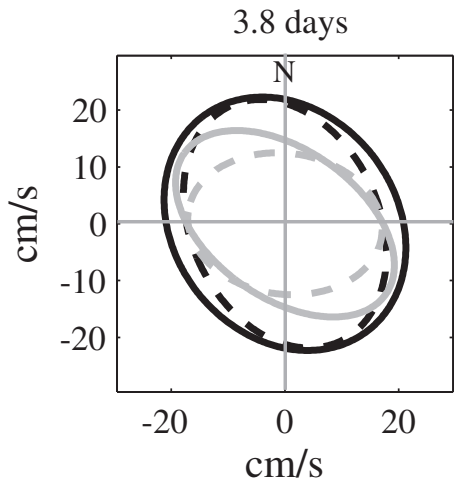

(b)
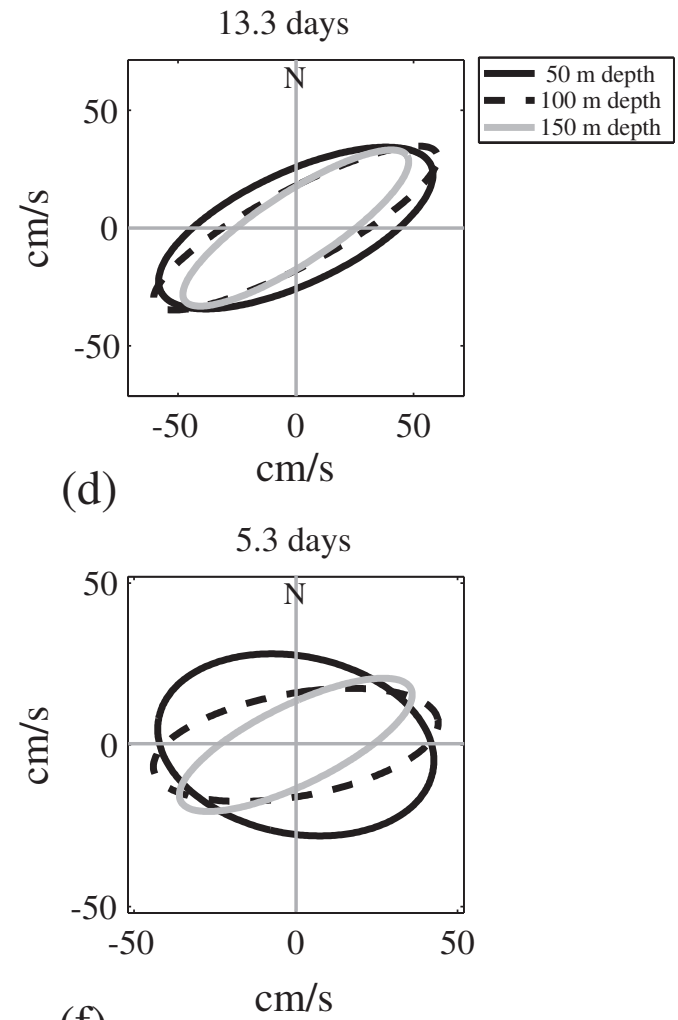

(f)

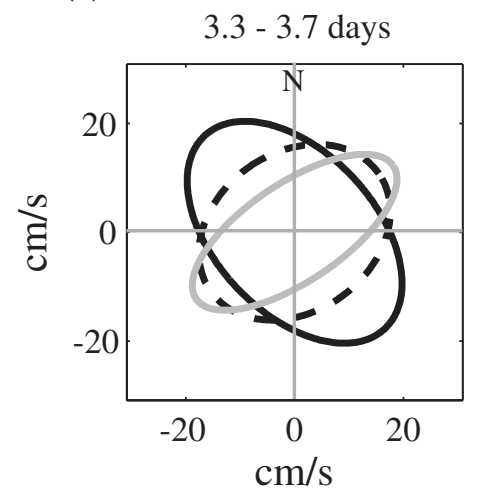


(a)

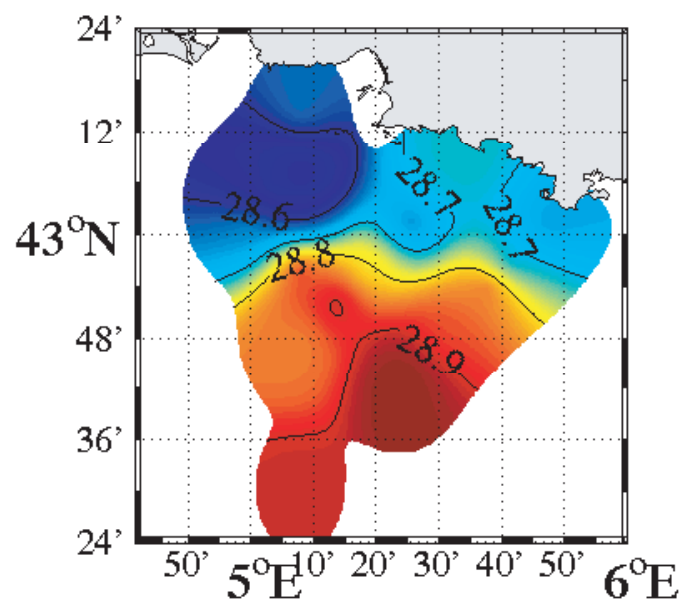

(c)

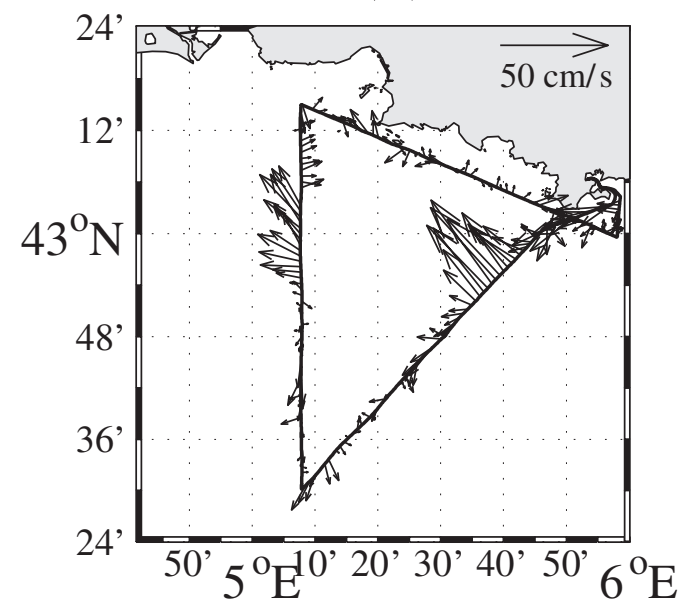

(b)

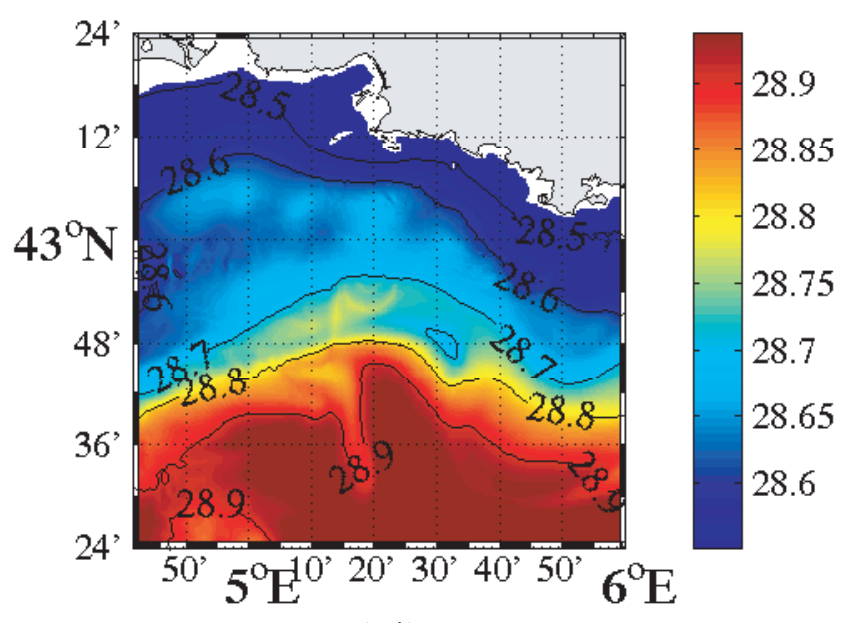

(d)

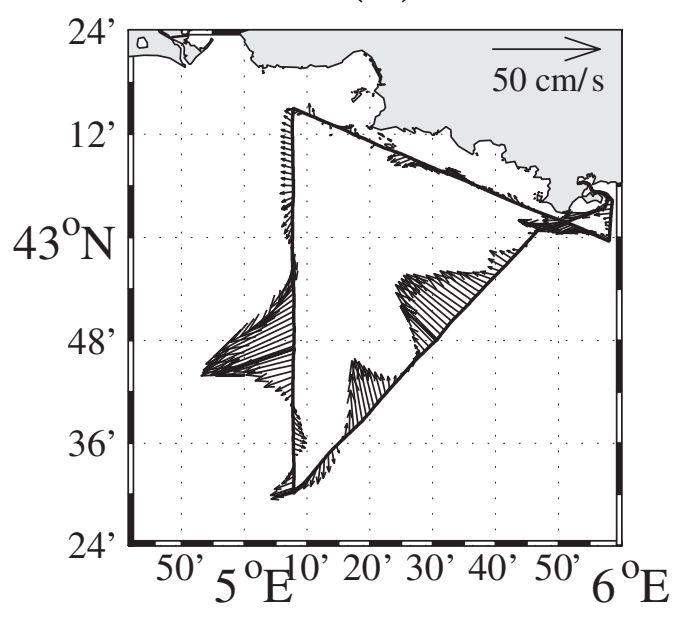


Figure 13

Click here to download high resolution image
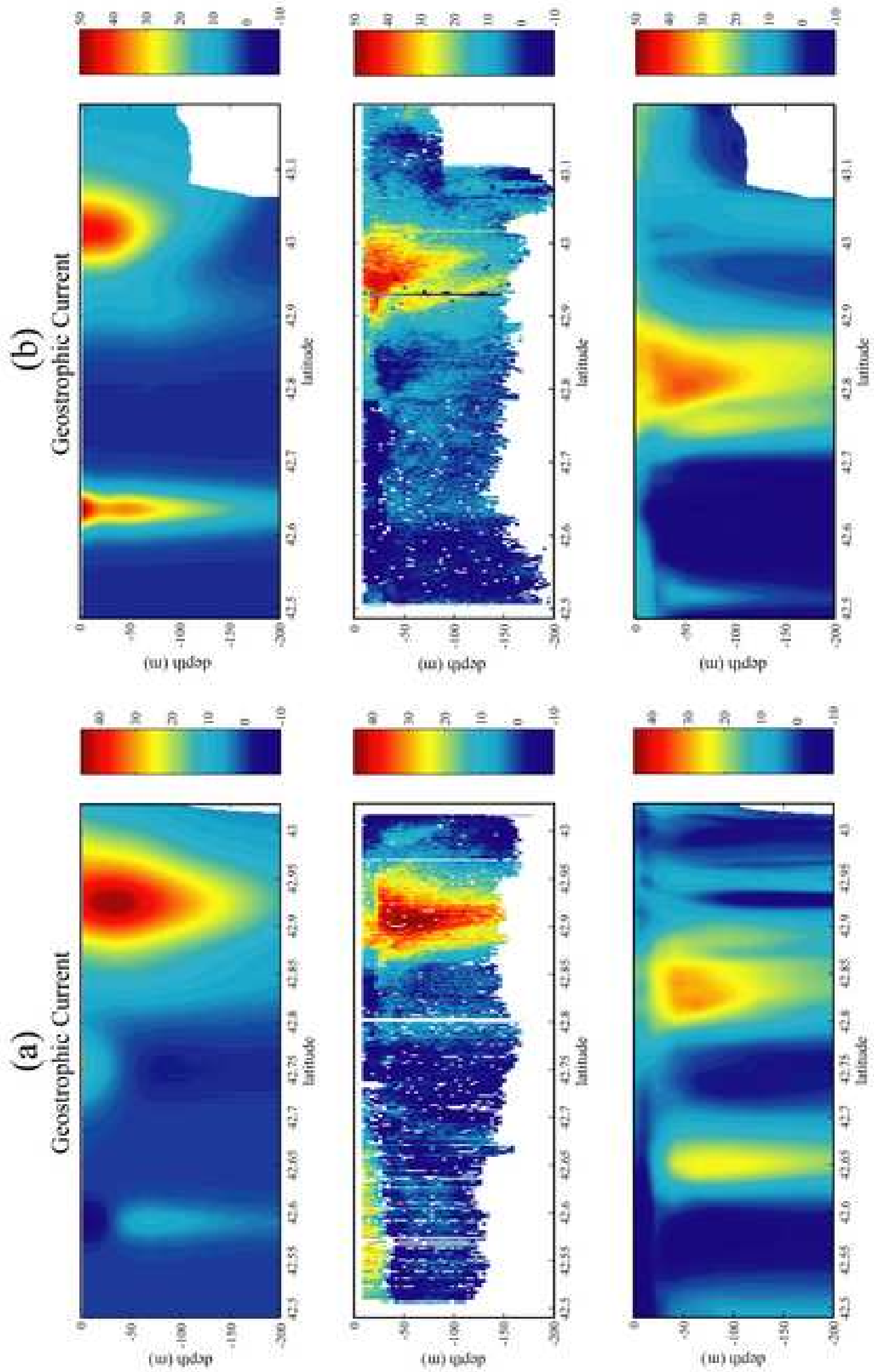
(a)

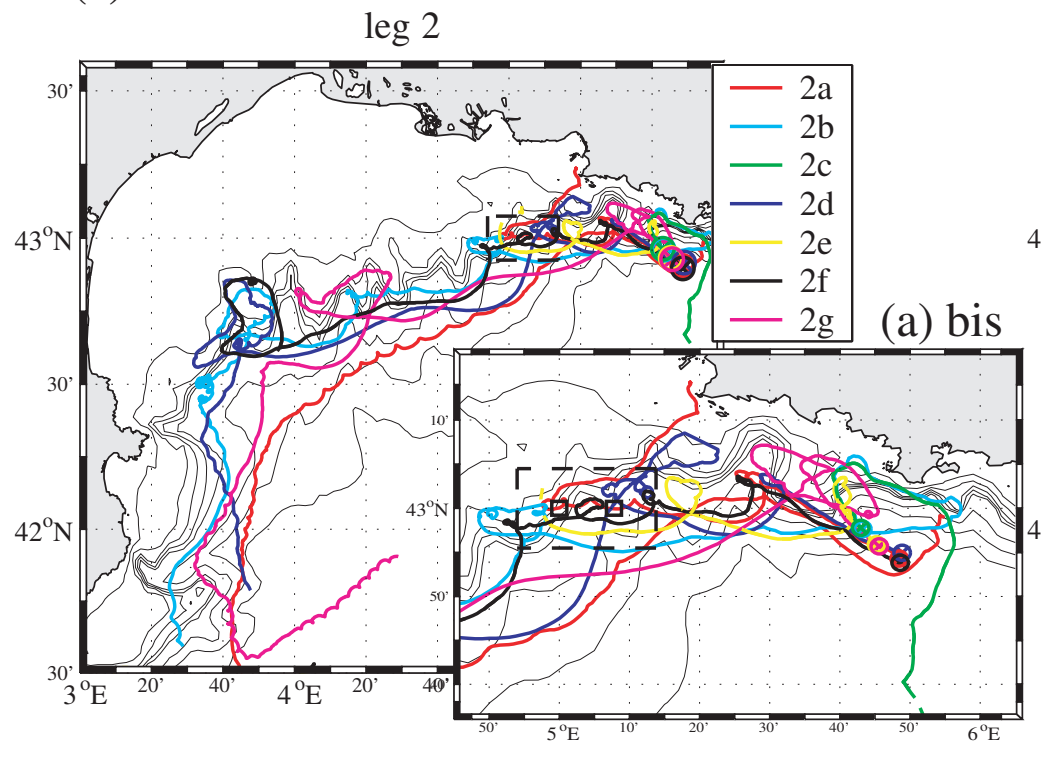

(c)

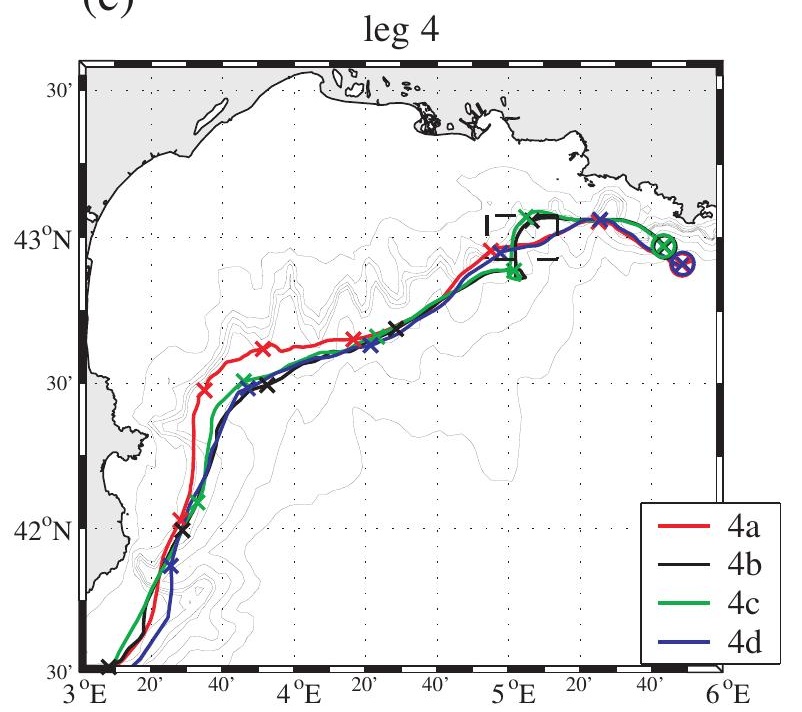

(b)

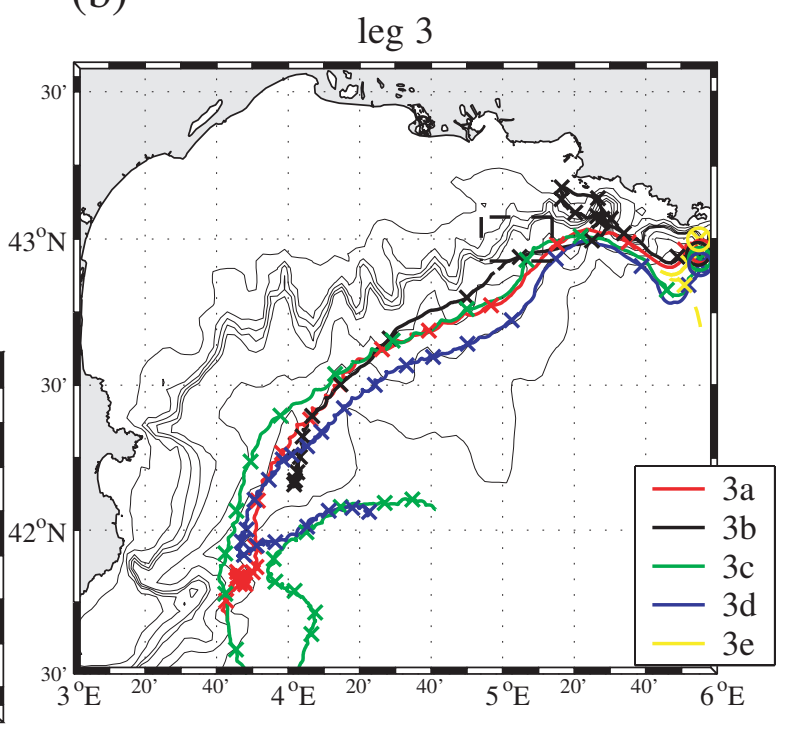

(d)

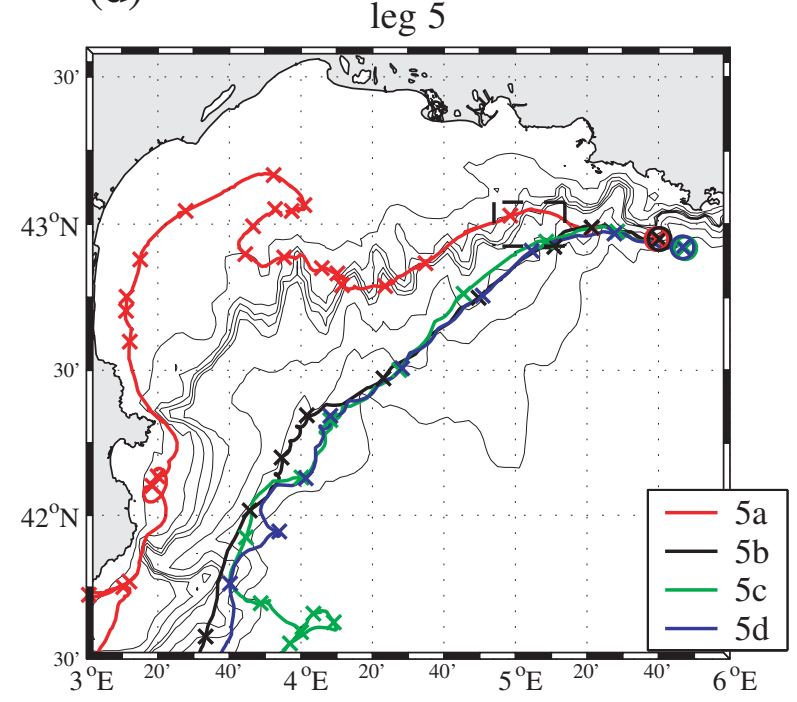


Figure 15

(a)

01-JUL-2005 15:00
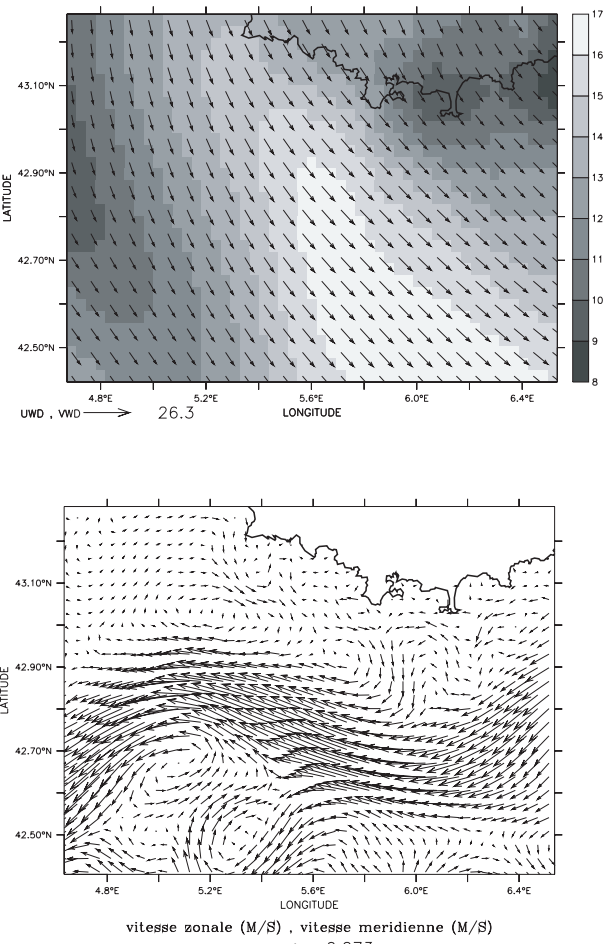

(b)
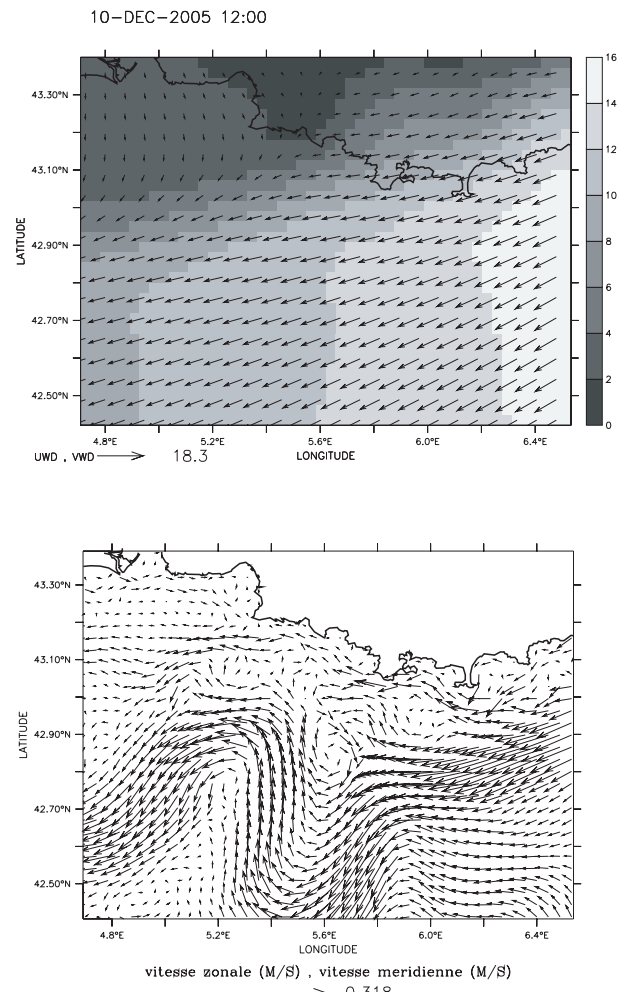

(c)
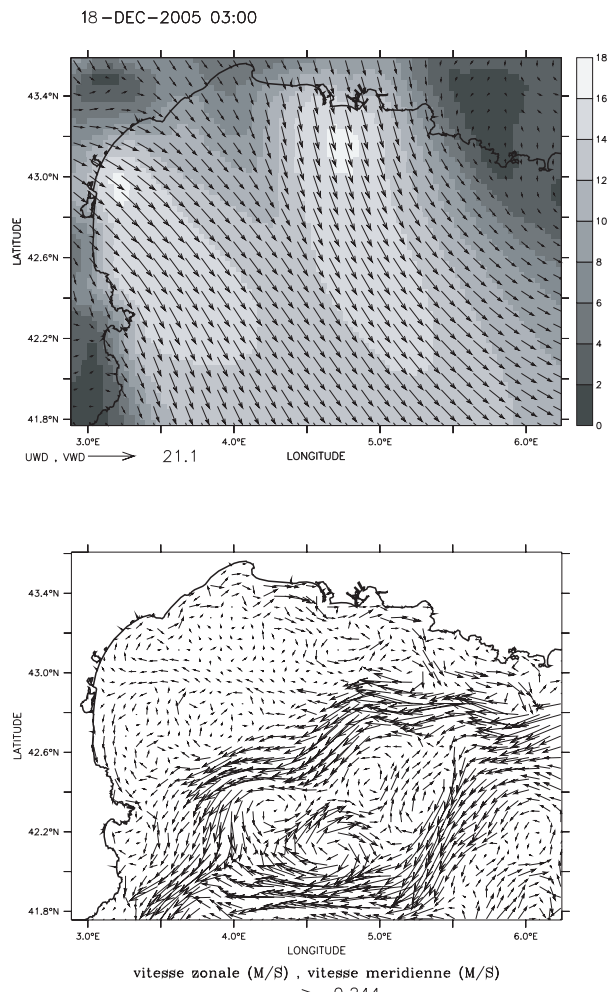
Figure 16a
Click here to download high resolution image

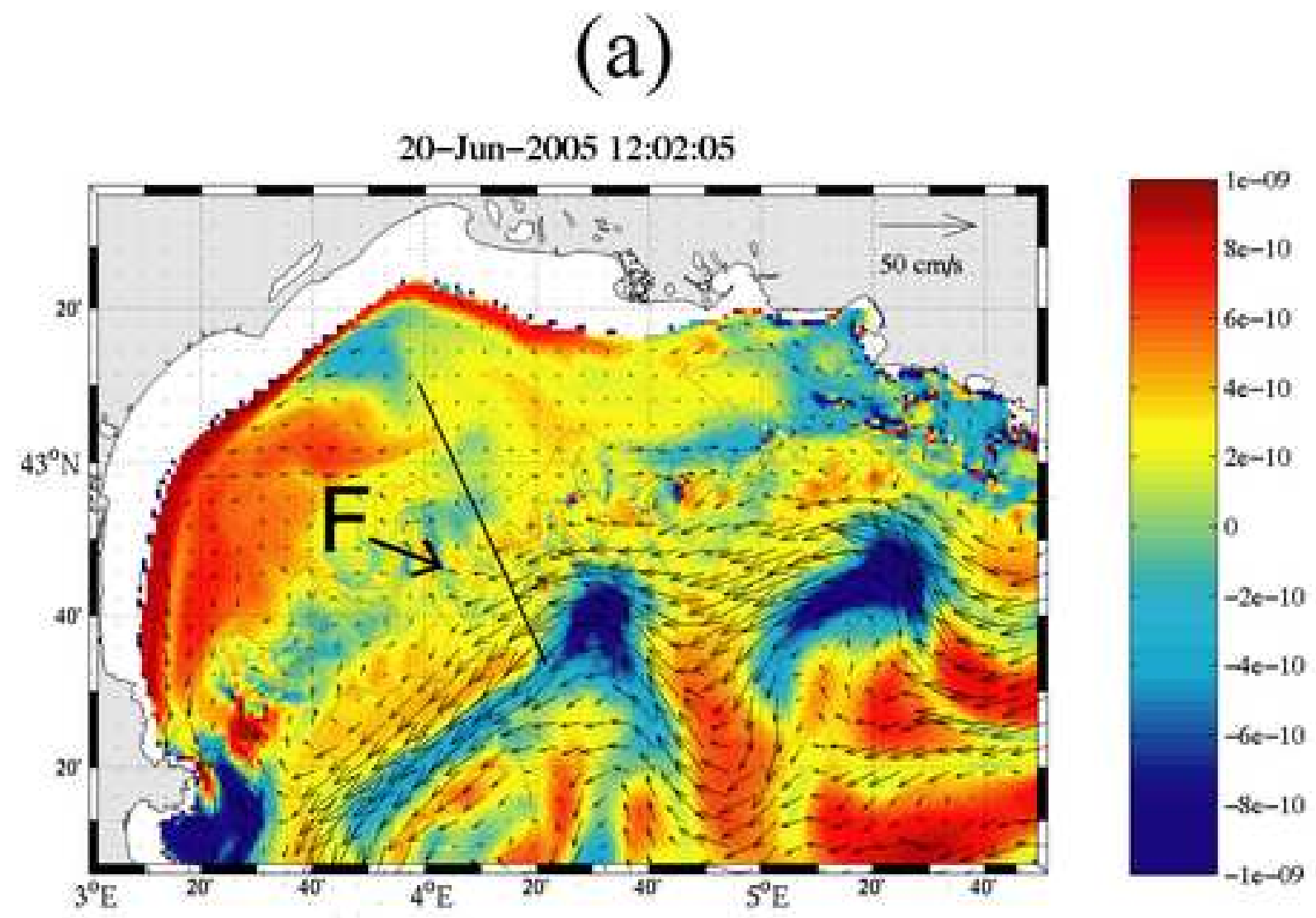


Figure $16 \mathrm{~b}$
Click here to download high resolution image

(b)

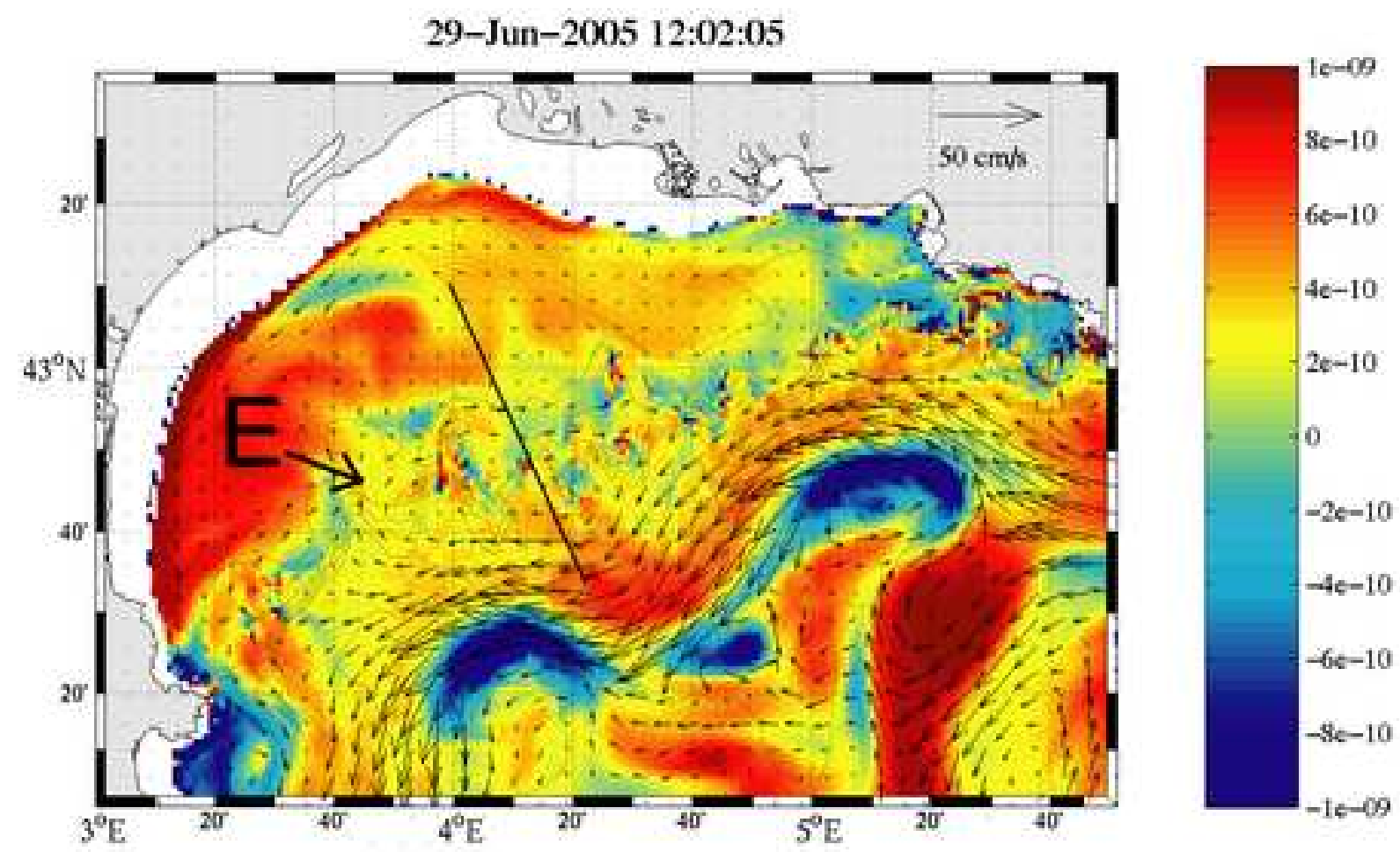


Click here to download Table: Table1_modif.xls

\begin{tabular}{|c|c|c|c|c|c|c|c|}
\hline Name & Depth & Start Date & Latitude & Longitude & End Date & $T$ & $\bar{V}$ \\
\hline & \multicolumn{6}{|c|}{ First Deployment } & \\
\hline $1 \mathrm{a}$ & $50 \mathrm{~m}$ & $05 / 29 / 2005$ & $42.954 \mathrm{~N}$ & $5.730 \mathrm{E}$ & $3 / 6 / 2005$ & 5 & 13 \\
\hline $1 b$ & $50 \mathrm{~m}$ & 05/29/2005 & $42.924 \mathrm{~N}$ & $5.816 \mathrm{E}$ & $3 / 6 / 2005$ & 5 & 15 \\
\hline $1 \mathrm{c}$ & $50 \mathrm{~m}$ & $05 / 29 / 2005$ & $42.985 \mathrm{~N}$ & $5.898 \mathrm{E}$ & $3 / 6 / 2005$ & 5 & 8 \\
\hline $1 d$ & $75 \mathrm{~m}$ & $05 / 29 / 2005$ & $42.917 \mathrm{~N}$ & $5.814 \mathrm{E}$ & $3 / 6 / 2005$ & 5 & 24.3 \\
\hline \multirow[t]{2}{*}{$1 \mathrm{e}$} & $50 \mathrm{~m}$ & $05 / 29 / 2005$ & $42.959 \mathrm{~N}$ & $5.723 \mathrm{E}$ & $3 / 6 / 2005$ & 5 & 12.9 \\
\hline & \multicolumn{6}{|c|}{ Second Deployment } & \\
\hline $2 \mathrm{a}$ & $50 \mathrm{~m}$ & $1 / 6 / 2005$ & $42.908 \mathrm{~N}$ & $5.821 \mathrm{E}$ & $5 / 8 / 2005$ & 65 & 10.3 \\
\hline $2 b$ & $50 \mathrm{~m}$ & $1 / 6 / 2005$ & $42.957 \mathrm{~N}$ & $5.726 \mathrm{E}$ & $1 / 8 / 2005$ & 61 & 11.7 \\
\hline $2 \mathrm{c}$ & $50 \mathrm{~m}$ & $1 / 6 / 2005$ & $42.960 \mathrm{~N}$ & $5.721 \mathrm{E}$ & $5 / 6 / 2005$ & 4 & 11.3 \\
\hline $2 d$ & $50 \mathrm{~m}$ & $1 / 6 / 2005$ & $42.915 \mathrm{~N}$ & $5.821 \mathrm{E}$ & 07/19/2905 & 47 & 13 \\
\hline $2 \mathrm{e}$ & $75 \mathrm{~m}$ & $1 / 6 / 2005$ & $42.93 \mathrm{~N}$ & $5.761 \mathrm{E}$ & $11 / 6 / 2005$ & 9 & 13.8 \\
\hline $2 \mathrm{f}$ & $75 \mathrm{~m}$ & $1 / 6 / 2005$ & $42.896 \mathrm{~N}$ & $5.819 \mathrm{E}$ & $4 / 7 / 2005$ & 33 & 11.3 \\
\hline \multirow[t]{2}{*}{$2 g$} & $50 \mathrm{~m}$ & $1 / 6 / 2005$ & $42.926 \mathrm{~N}$ & $5.767 \mathrm{E}$ & $07 / 23 / 2005$ & 52 & 13 \\
\hline & \multicolumn{6}{|c|}{ Third Deployment } & \\
\hline $3 a$ & $50 \mathrm{~m}$ & $3 / 7 / 2005$ & $42.958 \mathrm{~N}$ & $5.925 \mathrm{E}$ & $08 / 14 / 2005$ & 42 & 10 \\
\hline $3 b$ & $50 \mathrm{~m}$ & $3 / 7 / 2005$ & $42.95 \mathrm{~N}$ & $5.915 \mathrm{E}$ & $08 / 15 / 2005$ & 43 & 8.7 \\
\hline $3 \mathrm{c}$ & $50 \mathrm{~m}$ & $3 / 7 / 2005$ & $42.933 \mathrm{~N}$ & $5.917 \mathrm{E}$ & $08 / 19 / 2005$ & 47 & 12.3 \\
\hline $3 d$ & $75 \mathrm{~m}$ & $3 / 7 / 2005$ & $42.914 \mathrm{~N}$ & $5.92 \mathrm{E}$ & 08/20/2005 & 48 & 9 \\
\hline \multirow[t]{2}{*}{$3 e$} & $50 \mathrm{~m}$ & $3 / 7 / 2005$ & $42.998 \mathrm{~N}$ & $5.913 \mathrm{E}$ & $7 / 7 / 2005$ & 4 & 13.4 \\
\hline & \multicolumn{6}{|c|}{ Fourth Deployment } & \\
\hline $4 a$ & $50 \mathrm{~m}$ & $1 / 12 / 2005$ & $42.907 \mathrm{~N}$ & $5.806 \mathrm{E}$ & $01 / 18 / 2006$ & 42 & 22.4 \\
\hline $4 b$ & $50 \mathrm{~m}$ & $1 / 12 / 2005$ & $42.973 \mathrm{~N}$ & $5.730 \mathrm{E}$ & $12 / 15 / 2005$ & 14 & 31.5 \\
\hline $4 c$ & $50 \mathrm{~m}$ & $1 / 12 / 2005$ & $42.974 \mathrm{~N}$ & $5.720 \mathrm{E}$ & $12 / 23 / 2005$ & 22 & 30.2 \\
\hline $4 \mathrm{~d}$ & $50 \mathrm{~m}$ & $1 / 12 / 2005$ & $42.911 \mathrm{~N}$ & $5.810 \mathrm{E}$ & $11 / 12 / 2005$ & 11 & 29.2 \\
\hline \multicolumn{8}{|c|}{ Fifth Deployment } \\
\hline $5 a$ & $50 \mathrm{~m}$ & $8 / 12 / 2005$ & $42.908 \mathrm{~N}$ & $5.821 \mathrm{E}$ & $01 / 30 / 2006$ & 52 & 14.9 \\
\hline $5 b$ & $50 \mathrm{~m}$ & $8 / 12 / 2005$ & $42.957 \mathrm{~N}$ & $5.726 \mathrm{E}$ & $01 / 31 / 2006$ & 53 & 14.9 \\
\hline $5 \mathrm{c}$ & $50 \mathrm{~m}$ & $8 / 12 / 2005$ & $42.908 \mathrm{~N}$ & $5.821 \mathrm{E}$ & 01/19/2006 & 41 & 19.6 \\
\hline $5 d$ & $50 \mathrm{~m}$ & $8 / 12 / 2005$ & $42.957 \mathrm{~N}$ & $5.726 \mathrm{E}$ & $01 / 19 / 2006$ & 41 & 19.6 \\
\hline
\end{tabular}




\begin{tabular}{|c|c|c|}
\hline \multirow[t]{2}{*}{ Resolution: } & Horizontal: & $400 \mathrm{~m}$ \\
\hline & Temporal: & $150 \mathrm{~s}$ \\
\hline \multicolumn{2}{|c|}{ Number of sigma layer: } & 30 \\
\hline \multicolumn{2}{|c|}{ Spin-up } & 1 month \\
\hline \multirow{3}{*}{ Forcing: } & M eteorological: & $\begin{array}{l}\text { M M } 5 \text { atmospherical } \\
\text { model ( } 3 \mathrm{~km} ; 3 \mathrm{~h})\end{array}$ \\
\hline & Open boundary: & $\begin{array}{c}\text { NORM ED } \\
\text { configuration } \\
\text { (1.2 km; } 3 \mathrm{~h})\end{array}$ \\
\hline & River runoff: & $\begin{array}{l}\text { Daily Rhone river } \\
\text { outflow }\end{array}$ \\
\hline \multirow{2}{*}{$\begin{array}{l}\text { Vertical viscosity: } \\
\text { (Pacanowsky and } \\
\text { Philander 1981) }\end{array}$} & M inimum: & $1.10^{-5} \mathrm{~m}^{2} \cdot \mathrm{s}^{-1}$ \\
\hline & maximum: & $5.10^{-3} \mathrm{~m}^{2} \cdot \mathrm{s}^{-1}$ \\
\hline \multirow{3}{*}{$\begin{array}{c}\text { Horizontal } \\
\text { viscosity: } \\
\text { (Smagorinsky, 1963) }\end{array}$} & Coefficient & 0.25 \\
\hline & M inimum $V$ alue & $1 \mathrm{~m}^{2} \cdot \mathrm{s}^{-1}$ \\
\hline & $M$ aximum $V$ alue & $200 \mathrm{~m}^{2} \cdot \mathrm{s}^{-1}$ \\
\hline \multicolumn{2}{|c|}{ H orizontal diffusivity: } & $1 \mathrm{~m}^{2} \cdot \mathrm{s}^{-1}$ \\
\hline
\end{tabular}

